\title{
Neoadjuvant Treatment Options in Soft Tissue Sarcomas
}

\author{
Mateusz Jacek Spałek 1,*D, Katarzyna Kozak ${ }^{1}$, Anna Małgorzata Czarnecka 1,2, \\ Ewa Bartnik $^{3,4}$ (D) Aneta Borkowska ${ }^{1}$ and Piotr Rutkowski ${ }^{1}$ (D) \\ 1 Department of Soft Tissue/Bone Sarcoma and Melanoma, Maria Sklodowska-Curie National Research \\ Institute of Oncology, 02-781 Warsaw, Poland; wiatrowka@gmail.com (K.K.); \\ am.czarnecka@pib-nio.pl (A.M.C.); aneta.borkowska@pib-nio.pl (A.B.); piotr.rutkowski@pib-nio.pl (P.R.) \\ 2 Department of Experimental Pharmacology, Mossakowski Medical Research Centre, Polish Academy of \\ Sciences, 02-106 Warsaw, Poland \\ 3 Institute of Genetics and Biotechnology, Faculty of Biology, University of Warsaw, 02-106 Warsaw, Poland; \\ ewambartnik@gmail.com \\ 4 Institute of Biochemistry and Biophysics, Polish Academy of Sciences, 02-106 Warsaw, Poland \\ * Correspondence: mateusz.spalek@pib-nio.pl; Tel.: +48-22-546-24-55
}

Received: 26 June 2020; Accepted: 24 July 2020; Published: 26 July 2020

\begin{abstract}
Due to the heterogeneity of soft tissue sarcomas (STS), the choice of the proper perioperative treatment regimen is challenging. Neoadjuvant therapy has attracted increasing attention due to several advantages, particularly in patients with locally advanced disease. The number of available neoadjuvant modalities is growing continuously. We may consider radiotherapy, chemotherapy, targeted therapy, radiosensitizers, hyperthermia, and their combinations. This review discusses possible neoadjuvant treatment options in STS with an emphasis on available evidence, indications for each treatment type, and related risks. Finally, we summarize current recommendations of the STS neoadjuvant therapy response assessment.
\end{abstract}

Keywords: soft tissue sarcoma; neoadjuvant treatment; combined treatment

\section{Introduction}

Due to the growing number of available treatment options and the rarity and heterogeneity of soft tissue sarcomas (STS), the decision-making process is very complex. In comparison to surgery alone, the addition of adjuvant radiotherapy (RT) allows obtaining a high local control rate in patients with STS of extremities or trunk wall. Nevertheless, this combination does not improve patients' overall survival (OS) [1]. Additional treatment modalities may help to improve local and distant disease control. Perioperative anthracycline-based chemotherapy (CHT) should be considered in high-risk STS [2]. However, its efficacy is still under debate. Hyperthermia (HT) may enhance the effect of both RT and CHT, but it has not been widely adopted in clinical practice [3-6]. Another novel approach includes the radiosensitization of sarcoma cells by the targeted treatment given concurrently with RT [7]. Other modalities, such as radiosensitizing nanoparticles, gave promising preliminary results, but are still under investigation in trials [8].

The introduction of neoadjuvant treatments in clinical practice was initially limited to challenging cases, such as unresectable STS, albeit currently it should be considered as an equal alternative to adjuvant therapy, bringing more advantages than risks. It is highly improbable to create a universal neoadjuvant treatment regimen for STS due to the variety of molecular subtypes and related clinical factors [9]. Thus, any clinical decision must be individualized and analyzed by STS multidisciplinary tumor board (MTB). Patients with locally advanced STS should be enrolled in clinical trials with 
neoadjuvant treatment; however, their availability is poor. This article summarizes the available evidence, research directions, assessment of response, and practical aspects of neoadjuvant treatment that may be helpful in the management of patients with localized STS. The options include RT, CHT, targeted therapy, HT, nanoparticles, and their combinations. Selected STS types, such as dermatofibrosarcoma protuberans, gastrointestinal stromal tumor, rhabdomyosarcoma, and Ewing sarcoma, have separate, established treatment strategies that are beyond the scope of this review.

\section{Neoadjuvant Treatment Options}

\subsection{Radiotherapy}

\subsubsection{Considerations and Available Evidence}

Despite several advantages of neoadjuvant RT in STS and no differences in long-term outcomes as compared to adjuvant RT, neoadjuvant treatment is not widely used in clinical practice (Table 1) [10]. The main concern of neoadjuvant RT is an increase in wound complications, as described below [11]. Other important RT-related issues are delineation, RT technique, fractionation, and a postoperative boost in case of non-radical surgery.

Table 1. Comparison of neoadjuvant and adjuvant radiotherapy in soft tissue sarcomas.

\begin{tabular}{lll}
\hline \multicolumn{1}{c}{ Issue } & Adjuvant Radiotherapy & Neoadjuvant Radiotherapy \\
\hline Delineation & $\begin{array}{l}\text { Complicated (no GTV, fusion with } \\
\text { preoperative imaging, } \\
\text { postoperative changes) } \\
\text { Larger (tumor bed, scars, drainage, } \\
\text { operative route, and margins) }\end{array}$ & Easy (visible GTV) \\
Target volume & Move to the tumor bed & Pmaller (GTV + margin) \\
Healthy tissues & Higher (60-66 Gy EQD2) & Lower (45-50.4 Gy EQD2) \\
Treatment time & Longer & Shorter \\
Hypofractionation & No/not known & Possible \\
Pathological assessment & Unhindered & Hindered \\
Tumor response & None & Possible \\
Resection margins & No influence & Could improve \\
Tumor seeding during resection & No influence & Possible reduction \\
Risk of early toxicity ${ }^{1}$ & Lower & Higher \\
Risk of late toxicity ${ }^{1}$ & Higher & Lower \\
Combination with chemotherapy & Possible & Possible \\
\hline
\end{tabular}

${ }^{1}$ In conventionally fractionated radiotherapy; abbreviations: EQD2-equivalent total dose in 2-Gy fractions; GTV—gross tumor volume.

In neoadjuvant RT, it is recommended to contour gross tumor volume (GTV) using magnetic resonance imaging (MRI) T1 post-gadolinium [12]. Clinical target volume (CTV) should be created by expanding GTV with adequate margins with additional coverage of tumor-related edema in MRI T2. In deep STS of extremities, CTV constitutes GTV $+1.5-2.0 \mathrm{~cm}$ radially and $4 \mathrm{~cm}$ longitudinally. In the case of superficial STS or trunk STS, there are no clear recommendations; however, it seems reasonable to add at least $4 \mathrm{~cm}$ in each direction along paths of least resistance stopping at anatomical barriers. Besides regular organs at risk adequate to the anatomic site, attention must be paid to healthy skin and subcutaneous tissue, as well as the second limb, large joints, and bones. Margins in STS RT seem to be extensive. However, there is no reliable evidence to support their reduction. The only phase II Radiation Therapy Oncology Group (RTOG) 0630 non-randomized clinical trial showed that image-guided RT with concomitant margin reduction results in low late toxicity while maintaining reasonable local control in comparison to Canadian trial data [13]. Nevertheless, the numerical comparison between the RTOG-0630 and the Canadian trial is not relevant due to the difference in RT techniques. In the 
RTOG-0630 trial, 75\% of patients were irradiated with intensity-modulated RT (IMRT), whereas in the Canadian trial in all patients older RT techniques were used [11,13].

RT techniques in STS slowly evolved from 3D-conformal RT to IMRT. IMRT allows better coverage of target volumes with the prescribed dose along with higher conformity but at the cost of an increase in volume irradiated with low doses [14]. Theoretically, irradiation of the whole extremity circumference may lead to persistent lymphedema. For this reason, many radiation oncologists have avoided using IMRT in STS. This hypothesis was not confirmed in the RTOG-0630 trial, as well as in other studies with IMRT in STS. O'Sullivan et al. conducted a phase II non-randomized prospective clinical trial with RT in STS, in which IMRT resulted in favorable functional outcomes [15]. Another analysis by Peeken et al. confirmed the good toxicity profile of tomotherapy-based IMRT in patients with STS [16].

Neoadjuvant RT in STS may be prescribed in conventional and altered fractions [17]. The conventional fractionation is 50-50.4 Gy in 25-28 fractions for 5-6 weeks; however, it is not evidence-based. Several attempts of hypofractionated RT (HFRT) were described in the literature $[7,18]$. The alpha/beta ratio of STS is presumably lower than $10 \mathrm{~Gy}$ and closer to radioresistant tumors such as prostate cancer [19-21]. As per the generalized linear-quadratic model, a higher dose per fraction applied to tumors with a lower alpha/beta ratio should result in better tumor control [22]. HFRT has other advantages such as shorter overall treatment time, better adherence to therapy, and higher cost-effectiveness [23,24]. However, HFRT has been validated only in phase I and phase II clinical trials in STS. Thus, it is recommended to use HFRT only in further trials or in individually selected cases upon MTB decision [7].

Unfortunately, even the best perioperative treatment cannot replace high-quality R0 surgery [25]. It has been shown that the addition of a postoperative RT boost after neoadjuvant RT and non-radical surgery does not improve local control in STS [26,27]. Nonetheless, it is still considered optional in the National Comprehensive Cancer Network (NCCN) guidelines [28].

Novel neoadjuvant RT approaches in STS include a return to abandoned spatially fractionated RT that used sieve-like collimators to produce fluctuating dose distribution with extremely high doses in selected subvolumes of a tumor. Mohiuddin et al. used spatially fractionated RT with ifosfamide-based CHT to treat bulky STS, obtaining excellent pathological responses and acceptable toxicity [29]. Dynamic RT techniques could emulate a grid-like pattern within the tumor without the use of a designed collimator. This technique is called LATTICE RT [30]. Prospective trials with LATTICE RT in locally advanced STS are awaited. Brachytherapy is not discussed in this review, because it is given intraoperatively or as an adjuvant treatment.

\subsubsection{Indications}

According to the NCCN guidelines, neoadjuvant RT is recommended as one of the possible options in stage II, III resectable extremity, superficial trunk, or head/neck STS with acceptable functional outcomes (category 1) [28]. In the case of resectable stage II and III STS with predicted adverse functional outcomes and unresectable STS, NCCN recommends an attempt of neoadjuvant treatment, namely RT, CHT+RT, CHT, or regional limb therapy. European Society for Medical Oncology (ESMO) guidelines recommend surgery and perioperative RT as a standard treatment in high-grade (G2-3), deep, $>5 \mathrm{~cm}$ STS [31]. The sequence of RT and surgery should be selected based on the risk of wound complications. There is no consensus regarding other clinical situations, i.e., high-grade, deep, $<5 \mathrm{~cm}$ STS; high-grade, superficial, $>5 \mathrm{~cm}$ STS; low-grade, deep, $>5 \mathrm{~cm}$ STS. RT should be discussed at MTB, and the risk of local relapse, pathology, and potential toxicity should be considered.

\subsubsection{Risks}

The most significant disadvantage of neoadjuvant RT is the increased risk of wound complications. In the Canadian trial, authors randomized patients to neoadjuvant or adjuvant RT [11]. Due to the higher occurrence of wound complications in the neoadjuvant group ( $35 \%$ vs. $17 \%$ ), the trial was prematurely stopped. However, after a longer follow-up, more patients after adjuvant RT, than patients 
after neoadjuvant RT, developed fibrosis-related late RT toxicity [32]. What is important, even serious wound complications are reversible, whereas fibrosis-related late toxicities are usually permanent, progressive, and may severely deteriorate the patients' quality of life [33]. Several patient-dependent factors increase the ratio of wound complications, such as STS localization (lower extremity and $<3 \mathrm{~mm}$ from the skin), tumor size $>10 \mathrm{~cm}$, concomitant diseases as diabetes, obesity, as well as smoking [34-36]. Treatment-related factors that exacerbate wound complications are related to RT (as described above) and surgery (split-thickness skin graft or vascularized flap closure).

\subsection{Chemotherapy}

\subsubsection{Considerations and Available Evidence}

The role of perioperative CHT in patients with localized STS remains controversial [37]. Neoadjuvant CHT should result in tumor burden reduction and subsequently facilitate radical surgery. In particular, $\mathrm{CHT}$ is expected to downstage the tumor in the case of marginally resectable STS allowing for more conservative operation [38]. Neoadjuvant CHT enables the elimination of micrometastases before massive release of cytokines induced by surgery. Finally, it should improve patient survival [39]. The neoadjuvant approach eliminates the risk of adjuvant CHT-related wound complications. Moreover, in routine clinical practice performance, the status of patients is often better before extensive surgery, enabling a more toxic but also more efficient neoadjuvant $\mathrm{CHT}$ regimen [40]. Better performance status indirectly allows adequate $\mathrm{CHT}$ dose intensity and promotes compliance. However, evidence-based confirmation of these clinical hypotheses is scarce [41].

An updated large meta-analysis of 18 randomized controlled trials of adjuvant CHT for localized resectable STS showed that anthracycline-based CHT marginally improved local recurrence, distant recurrence, overall recurrence, and OS [42]. Even less evidence justifies the use of CHT alone in a neoadjuvant setting in STS. In 2001, Eilber et al. published the results of neoadjuvant CHT of patients with locally advanced STS showing a higher percentage of pathological responses and better survival in patients receiving an ifosfamide-based regimen in comparison with patients receiving doxorubicin-based CHT (without ifosfamide) [43]. There is a lack of randomized phase III clinical trials in the field. The results of available smaller studies are contradictory [44-46]. In a randomized phase II clinical trial by the European Organisation for Research and Treatment of Cancer Soft Tissue Bone Sarcoma Group (EORTC-STBSG) and the National Cancer Institute of Canada Clinical Trials Group/Canadian Sarcoma Group on neoadjuvant CHT for high-risk STS, neoadjuvant CHT followed by surgery failed to show better survival than surgery alone [47]. Thus, expansion to phase III was abandoned. In the above-mentioned trial, 134 patients with resectable high-risk primary and recurrent STS were randomized to a surgery alone arm or to three cycles of doxorubicin+ifosfamide (AI) with a subsequent surgery arm. This regimen was reasonably tolerated and did not compromise surgery. Disappointingly, it resulted in unsatisfactory benefit in 5-year disease-free survival in comparison to surgery alone (56\% vs. 52\%) [35]. This trial was criticized for inclusion of patients with both primary and recurrent tumors as well as patients with low grade STS [48].

Histologically driven CHT showed good preliminary efficacy of selected drugs in chosen pathological STS subtypes. Four sarcoma groups (French, Spanish, Polish, and Italian) performed a phase III randomized clinical trial (NCT01710176) with neoadjuvant histologically driven CHT $[49,50]$. Two hundred seventy-eight patients with STS were enrolled in the trial. The patients received three cycles of epirubicin+ifosfamide (EI) or histologically driven CHT: for myxoid liposarcoma-trabectedin, for leiomyosarcoma-gemcitabine+dacarbazine, for synovial sarcoma-ifosfamide, for malignant peripheral nerve sheath tumor (MPNST)—etoposide+ifosfamide, and for pleomorphic sarcoma-gemcitabine+docetaxel. Surprisingly, after the median 52 months of follow-up, there were no differences between histologically driven CHT and EI in disease-free survival ( $47 \%$ in the tailored arm, $55 \%$ in EI arm, hazard ratio [HR] 1.23, 95\% CI 0.88-1.73). Moreover, OS was shorter in the histologically driven arm in comparison to the EI arm (66\% vs. $76 \%$, HR 1.77, 95\% 
CI 1.10-2.83). As a result of this trial, anthracycline-based regimens remain preferred CHT in STS regardless of histological subtype. This study also confirms that in STS patients with $60-70 \%$ risk of relapse, three cycles of neoadjuvant anthracycline+ifosfamide $\mathrm{CHT}$ are associated with an absolute benefit of $20 \%$ for relapse-free survival and OS.

The optimal number of CHT cycles was addressed in a study conducted by the Italian Sarcoma Group and the Spanish Sarcoma Group [51-53]. The researchers compared three cycles of neoadjuvant AI CHT with five cycles of the same regimen given perioperatively (three neoadjuvant cycles, surgery, two adjuvant cycles). No benefit in survival was detected between the analyzed groups. Thus, three cycles of neoadjuvant anthracycline+ifosfamide may still be considered as a preferred regimen in STS including epirubicin $120 \mathrm{mg} / \mathrm{m}^{2}$ with ifosfamide $9 \mathrm{~g} / \mathrm{m}^{2}$ [42].

The randomized trials with neoadjuvant CHT regimens in STS are presented in Table 2.

Table 2. Neoadjuvant chemotherapy in soft tissue sarcomas.

\begin{tabular}{|c|c|c|c|c|c|c|}
\hline $\begin{array}{l}\text { Authors and Type } \\
\text { of Study }\end{array}$ & $\mathbf{N}$ & Treatment Arms & $\begin{array}{l}\text { Perioperative } \\
\text { Radiotherapy }\end{array}$ & $\begin{array}{l}\text { Response } \\
\text { Rate }\end{array}$ & $\begin{array}{c}\text { Disease-Free } \\
\text { Survival @Years }\end{array}$ & $\begin{array}{c}\text { Overall } \\
\text { Survival @Years }\end{array}$ \\
\hline $\begin{array}{c}\text { Gortzak et al. } 2001 \\
\text { phase II }\end{array}$ & 67 & $3 \times A I+$ surgery & $46 \%$ & $28 \%$ & $56 \% @ 5 y$ & 65\%@5y \\
\hline randomized trial [47] & 67 & surgery & $54 \%$ & - & $52 \% @ 5 y$ & 64\%@5y \\
\hline $\begin{array}{c}\text { Gronchi et al. 2012, } 2016 \\
\text { phase III }\end{array}$ & 160 & $3 \times \mathrm{EI}+$ surgery & $97 \%$ & $23 \%$ & $56 \% @ 10 y$ & 64\%@10y \\
\hline randomized trial $[51,52]$ & 161 & $3 \times \mathrm{EI}+$ surgery $+2 \times \mathrm{EI}$ & $93 \%$ & $19 \%$ & $58 \% @ 10 y$ & $59 \% @ 10 y$ \\
\hline Gronchi et al. 2017, 2019 & 145 & $3 \times \mathrm{EI}+$ surgery & $79 \%$ & $14 \%$ & $55 \% @ 5 y$ & $76 \% @ 5 y$ \\
\hline $\begin{array}{l}\text { phase III } \\
\text { randomized trial }[49,50]\end{array}$ & 142 & $\begin{array}{l}\text { histologically driven } \\
\text { CHT + surgery }\end{array}$ & $80 \%$ & $6 \%$ & 47\%@5y & 66\%@5y \\
\hline
\end{tabular}

Abbreviations: AI-doxorubicin, ifosfamide; CHT—chemotherapy; EI-epirubicin, ifosfamide; $\mathrm{N}-$ number of patients; NR-not reported.

\subsubsection{Indications}

An advantage of neoadjuvant CHT, especially if used in combination with RT, is an improvement in the effectiveness of surgery and therefore significant improvement in patient function and postoperative quality of life. Neoadjuvant CHT may be a valuable option in patients with a low probability of OS calculated using the prognostic nomogram Sarculator [54,55]. Moreover, neoadjuvant CHT may provide benefit in patients with high-risk or marginally resectable STS [48,56,57]. NCCN suggests considering $\mathrm{CHT}$ as an addition to RT or as standalone neoadjuvant treatment in resectable stage II and III STS with predicted adverse functional outcomes, and in primarily unresectable STS [28]. ESMO recommends at least three cycles of neoadjuvant $\mathrm{CHT}$ with anthracycline+ifosfamide in selected high-risk STS patients [31]. However, the sensitivity of STS subtypes should be taken into account. The anthracycline+ifosfamide combination should be considered in more chemosensitive subtypes such as synovial sarcoma, pleomorphic sarcoma, liposarcoma and leiomyosarcoma. It is important to note that older patients ( $\geq 65$ years) or those with comorbidities may not be able to tolerate such intensive treatment. More intensive $\mathrm{CHT}$ increases the risk of serious adverse events without providing significant benefit. Given the limited role of ifosfamide in leiomyosarcoma, doxorubicin+dacarbazine may be an alternative, less toxic treatment option in this group of patients [58]. Other treatment regimens cannot be recommended outside clinical trials. It is crucial to mention marginally sensitive and chemoresistant STS subtypes such as epithelioid sarcoma, extraskeletal myxoid chondrosarcoma, clear cell sarcoma, solitary fibrous tumor, alveolar soft part sarcoma and inflammatory myofibroblastic tumor, where neoadjuvant CHT should not be given because of lack of efficacy [59].

\subsubsection{Risks}

In turn, a disadvantage could be a delay in surgical treatment in the case of resistance to CHT [60]. Then, in the case of tumor progression, neoadjuvant CHT should be stopped, and definitive local 
treatment should be performed. There is a theoretical risk of disease progression during CHT that will make surgery in primary resectable STS impossible.

Furthermore, complications of neoadjuvant CHT can considerably delay surgery and prolong overall treatment time. Toxicities depend on the used chemotherapeutic agents. Anthracyclines bring the risk of myelosuppression and cardiotoxicity, whereas ifosfamide may cause hemorrhagic cystitis, neurotoxicity, extensive vomiting, and myelosuppression [61-65]. Moreover, a combination of doxorubicin with ifosfamide could increase the frequency of the above-mentioned toxicities and febrile neutropenia [66].

\subsection{Radiochemotherapy}

\subsubsection{Considerations and Available Evidence}

$\mathrm{CHT}+\mathrm{RT}$ may be considered in patients with high-risk or marginally resectable STS [67]. The main aims are as follows:

Improve local control;

Symptom control, including pain relief;

Improve local response allowing for conservative surgery and negative resection margins;

Limit the metastatic spread and improve survival;

Sensitize cancer cells to RT with a possibility of RT dose reduction to avoid RT-related toxicity;

Obtain data regarding response to neoadjuvant treatment that may serve as a prognostic factor.

Guidelines favoring neoadjuvant CHT+RT are not based on high-level evidence [28,31,56,68]. The optimal sequence of treatment is unknown. CHT can be given before, after, or concomitantly with RT [55]. CHT administration before or during RT planning could serve as "stop-gap measure" giving more time for generation of complicated highly conformal RT plan [38]. Concomitant use of anthracyclines and RT brings the risk of extensive skin, mucosal, and cardiac toxicity. However, data from breast cancer studies do not confirm this hypothesis $[69,70]$. Studies on CHT+RT in adjuvant treatment for STS do not suggest a significant increase in toxicity, even in a subgroup of elderly patients [71,72]. In the sub-analysis of a phase III clinical trial that compared three neoadjuvant vs. three neoadjuvant and two adjuvant AI cycles, the investigator was allowed to add neoadjuvant or adjuvant conventionally fractionated RT (CFRT) to the CHT, with or without postoperative boost [53]. Neoadjuvant RT was started after the first CHT cycle and continued within the second and third $\mathrm{CHT}$ cycle. One hundred fifty-two patients received neoadjuvant CHT+RT. It has been shown that this combination is safe and does not have a negative impact on CHT dose intensity. The only noted significant toxicities were the slightly increased likelihood of wound complications and grade 4 thrombocytopenia.

In the literature, several attempts of the integration of neoadjuvant $\mathrm{CHT}+\mathrm{RT}$ were investigated $[7,18]$. Various CHT regimens may be combined with both CFRT and HFRT. Such regimens are under investigation in highly locally advanced or marginally resectable STS [57]. The long-term results of novel CHT+RT regimens are presented in Table 3. 
Table 3. Novel neoadjuvant radiochemotherapy regimens in soft tissue sarcomas.

\begin{tabular}{|c|c|c|c|c|c|c|}
\hline Authors and Type of Study & $\mathbf{N}$ & $\begin{array}{l}\text { Radiotherapy } \\
\text { Regimen }\end{array}$ & $\begin{array}{l}\text { Chemotherapy } \\
\text { Regimen }\end{array}$ & $\begin{array}{l}\text { Hematology } \\
\text { Toxicity }\end{array}$ & $\begin{array}{l}\text { Local Control } \\
\text { @Years }\end{array}$ & $\begin{array}{l}\text { Overall } \\
\text { Survival @Years }\end{array}$ \\
\hline $\begin{array}{l}\text { Temple et al. } 1997 \text { prospective } \\
\text { cohort [73] }\end{array}$ & 42 & $10 \times 3 G y$ & $\begin{array}{l}\text { Concurrent } \\
\text { ADM }\end{array}$ & not reported & 97\%@5y & 65\%@5y \\
\hline $\begin{array}{l}\text { Edmonson et al. } 2002 \text { phase II } \\
\text { clinical trial [74] }\end{array}$ & 39 & $25 \times 1.8 \mathrm{~Gy}$ & $\begin{array}{l}\text { Concurrent } \\
\text { IMAP }\end{array}$ & $\mathrm{G} 3+77 \%$ & $92 \% @ 5 y$ & 80\%@5y \\
\hline $\begin{array}{l}\text { DeLaney et al. } 2003 \text { phase II } \\
\text { clinical trial [75] }\end{array}$ & 48 & $22 \times 2$ Gy & $\begin{array}{l}\text { Interdigitated } \\
\text { MAID }\end{array}$ & $\begin{array}{l}\text { febrile } \\
\text { neutropenia } \\
25 \%\end{array}$ & 92\%@5y & $84 \% @ 5 y$ \\
\hline $\begin{array}{l}\text { Kraybill et al. } 2006 \text { phase II } \\
\text { clinical trial [76] }\end{array}$ & 64 & $22 \times 2$ Gy & $\begin{array}{l}\text { Interdigitated } \\
\text { MAID }\end{array}$ & G4 83\% & 90\%@3y & $75 \% @ 3 y$ \\
\hline $\begin{array}{l}\text { Ryan et al. } 2008 \text { phase II } \\
\text { clinical trial [77] }\end{array}$ & 25 & $8 \times 3.5$ Gy & $\begin{array}{l}\text { Concurrent } \\
\text { EPI+IFO }\end{array}$ & G4 $84 \%$ & $88 \% @ 2 y$ & $84 \% @ 2 y$ \\
\hline $\begin{array}{l}\text { MacDermed et al. } 2010 \\
\text { retrospective cohort [78] }\end{array}$ & 34 & $8 \times 3.5$ Gy & $\begin{array}{l}\text { Concurrent } \\
\text { IFO }\end{array}$ & G4 53\% & 89\% @5y & $45 \% @ 5 y$ \\
\hline $\begin{array}{l}\text { Hong et al. } 2013 \text { retrospective } \\
\text { cohort [79] }\end{array}$ & 66 & $22 \times 2$ Gy & $\begin{array}{l}\text { Interdigitated } \\
\text { MAID }\end{array}$ & $\begin{array}{l}\text { febrile } \\
\text { neutropenia } \\
10 \%\end{array}$ & 91\%@5y & 86\%@5y \\
\hline $\begin{array}{l}\text { Spalek et al. } 2019 \text { phase II } \\
\text { clinical trial [57] }\end{array}$ & 30 & $5 \times 5$ Gy & $\begin{array}{l}\text { Interdigitated } \\
\mathrm{AI}\end{array}$ & G3+ ${ }^{1} @ 26 \%$ & 97\%@1y & not reported \\
\hline
\end{tabular}

${ }^{1}$ Only grade 3 or higher toxicities that caused chemotherapy dose reduction or withdrawal; abbreviations: $\mathrm{ADM}$-doxorubicin; AI-doxorubicin, ifosfamide; EPI-epirubicin; FN—febrile neutropenia; G—grade; IFO—ifosfamide; IMAP—ifosfamide, mitomycin, doxorubicin, cisplatin; MAID—mesna, doxorubicin, ifosfamide, dacarbazine; $\mathrm{N}$-number of patients.

\subsubsection{Indications}

According to NCCN guidelines, $\mathrm{CHT}+\mathrm{RT}$ may be considered as a treatment option for patients with stage II, III resectable extremity, superficial trunk, or head/neck STS with acceptable functional outcomes; however, the recommendation is based upon lower-level evidence (category 2B) [28]. Furthermore, it is a treatment of choice in resectable stage II and III STS with predicted adverse functional outcomes, and primarily unresectable STS. Neoadjuvant RTH-CHTH may also provide a substantial clinical benefit allowing radical surgery in primary marginally or non-resectable STS [57].

\subsubsection{Risks}

The addition of CHT to RT may increase toxicity. Anthracycline-based regimens may exacerbate RT mucosal and skin reactions as well as cardiac toxicity when RT is applied to the thoracic area. Moreover, even in the case of sequential CHT+RT, a phenomenon called radiation recall may occur [80]. It is defined as an inflammatory reaction in previously irradiated volume after the administration of CHT agents. Severity and length of radiation recall may vary. Finally, CHT toxicity may interrupt RT administration causing gaps in the selected fractionation regimen. Additionally, RT-induced toxicity may simultaneously decrease CHT dose intensity.

\subsection{Targeted Therapy}

\subsubsection{Considerations and Available Evidence}

Targeted therapies inhibit specific molecules involved in the proliferation and growth of cancer cells, as well as intratumoral endothelial cells. Both vascular endothelial growth factor (VEGFR) and epidermal growth factor receptor (EGFR) are overrepresented in neoplastic cells playing an essential role in tumor angiogenesis, as well as the promotion and progression of oncogenesis and metastatic spread. Intratumoral endothelial cells are crucial in the biological effects of RT [81]. It was shown that inhibition of VEGFR and EGFR signaling pathways is an effective strategy in particular STS subtypes, and it also enhances the effect of RT in STS [82,83].

Various targeted drugs are currently investigated in metastatic STS, but also in neoadjuvant treatment, mostly with neoadjuvant RT. Despite promising efficacy, available data come from early-phase clinical trials, thus must be interpreted with caution. Moreover, some studies reported 
worrisome toxicity of neoadjuvant targeted therapy [7]. Further studies are necessary to use this combination in everyday clinical practice. Available reports on targeted therapies with or without neoadjuvant RT in STS are presented in Table 4.

Table 4. Neoadjuvant targeted therapies in soft tissue sarcomas.

\begin{tabular}{|c|c|c|c|c|}
\hline Type of Trial & Treatment Regimen & $\mathbf{N}$ & Results & Toxicity \\
\hline $\begin{array}{l}\text { phase II } \\
\text { non-randomized [84] }\end{array}$ & $\begin{array}{l}4 \text { doses of } \\
\text { bevacizumab (dose } \\
\text { every } 2 \mathrm{w})+\mathrm{RT} \\
28 \times 1.8 \mathrm{~Gy}(5.5 \mathrm{w})\end{array}$ & 20 & $\begin{array}{l}\geq 80 \% \text { necrosis in } \\
45 \% ; \text { pCR in } 15 \%\end{array}$ & $\begin{array}{l}\text { G3+ } 20 \% \text {; wound } \\
\text { complications } 20 \%\end{array}$ \\
\hline $\begin{array}{l}\text { phase II randomized } \\
\text { NCT01446809 [85] }\end{array}$ & $\begin{array}{l}\mathrm{AI}+\text { placebo }(2 \mathrm{w}) \mathrm{vs} \\
\mathrm{AI}+\text { pazopanib }(2 \mathrm{w}) \\
\text { and optional } \mathrm{RT}\end{array}$ & 21 & $\begin{array}{l}\text { no differences in } \\
\text { maximal SUV }\end{array}$ & $\begin{array}{l}\text { SAE: pazopanib } 64 \% \text {; } \\
\text { placebo } 57 \%\end{array}$ \\
\hline $\begin{array}{l}\text { phase I } \\
\text { non-randomized } \\
\text { PASART-1 [86] }\end{array}$ & $\begin{array}{l}\text { pazopanib } 400,600 \text { or } \\
800 \text { mg daily }(6 w)+R T \\
25 \times 2 \text { Gy }(5 w)\end{array}$ & 12 & $\begin{array}{l}\geq 80 \% \text { necrosis in } \\
>70 \% \text {; near } \mathrm{pCR} \text { in } \\
40 \%\end{array}$ & $\begin{array}{l}\text { G3+ hepatotoxicity } \\
27 \% \text {; wound } \\
\text { complications 20\% }\end{array}$ \\
\hline $\begin{array}{l}\text { phase II } \\
\text { non-randomized } \\
\text { NOPASS [87] }\end{array}$ & $\begin{array}{l}\text { pazopanib } 800 \mathrm{mg} \\
\text { daily }(3 \mathrm{w})\end{array}$ & 21 & $\begin{array}{l}\geq 50 \% \text { reduction in } \\
\text { SUV only in one } \\
\text { case }\end{array}$ & G3 $33.3 \%$; G4 ${ }^{1} 4.8 \%$ \\
\hline $\begin{array}{l}\text { phase II } \\
\text { non-randomized } \\
\text { PASART-2 [88] }\end{array}$ & $\begin{array}{l}\text { pazopanib } 800 \mathrm{mg} \\
\text { daily }(3 \mathrm{w})+\mathrm{RT} 18 \times 2 \\
\text { Gy }(3.5 \mathrm{w})\end{array}$ & not reported & terminated & not reported \\
\hline $\begin{array}{l}\text { phase I } \\
\text { non-randomized } \\
\text { NCT00864032 [89] }\end{array}$ & $\begin{array}{l}\text { sorafenib } 2 \times 200, \text { or } \\
200 / 400 \text { mg daily + RT } \\
25 \times 2 \text { Gy }(5 w)\end{array}$ & 8 & $\mathrm{pCR}$ in $38 \%$ & $\begin{array}{l}\text { G3+ } 50 \% \text { (in } 200 / 400 \\
\text { mg arm only); severe } \\
\text { wound complications } \\
38 \%\end{array}$ \\
\hline $\begin{array}{l}\text { phase I } \\
\text { non-randomized [90] }\end{array}$ & $\begin{array}{l}\text { sorafenib } 200,400 \text {, or } \\
2 \times 400 \text { mg daily started } \\
2 \mathrm{w} \text { before } \\
\text { chemotherapy }+3 \times \text { EI } \\
+ \text { RT } 8 \times 3.5 \text { Gy }(1.5 \mathrm{w})\end{array}$ & 16 & $\mathrm{pCR}$ in $44 \%$ & $\begin{array}{l}\text { G4 hematological } 88 \% \text {; } \\
\text { severe wound } \\
\text { complications } 38 \%\end{array}$ \\
\hline $\begin{array}{l}\text { phase II } \\
\text { non-randomized } \\
\text { SunRaSe [91] }\end{array}$ & $\begin{array}{l}\text { sunitinib } 25 \mathrm{mg} \text { or } 37.5 \\
\mathrm{mg} \text { daily }(7.5 \mathrm{w})+\mathrm{RT} \\
28 \times 1.8 \mathrm{~Gy}(5.5 \mathrm{w})\end{array}$ & 9 & pCR in $33 \%$ & $\begin{array}{l}\text { G3+ } 67 \% \text {; severe } \\
\text { wound complications } \\
22 \%\end{array}$ \\
\hline $\begin{array}{l}\text { phase Ib/II } \\
\text { non-randomized } \\
\text { SUNXRT [92] }\end{array}$ & $\begin{array}{l}\text { sunitinib doses } 37.5-50 \\
\mathrm{mg}(7.5 \mathrm{w})+\mathrm{RT} \\
28 \times 1.8 \mathrm{~Gy}(5.5 \mathrm{w})\end{array}$ & 9 & $\begin{array}{l}\text { terminated } \\
\text { (toxicity); necrosis } \\
\text { in } 75 \%\end{array}$ & $\begin{array}{l}\text { G3+ } 78 \% ; \mathrm{G} 3+ \\
\text { hepatotoxicity } 44 \% \text {; } \\
\text { G3+ late toxicity } 22 \%\end{array}$ \\
\hline
\end{tabular}

${ }^{1}$ Anastomotic leakage; abbreviations: AI-doxorubicin, ifosfamide; CHT-chemotherapy; EI-epirubicin, ifosfamide; G—grade; $p C R$ — pathological complete response; RT—radiotherapy; SAE—serious adverse event; SUV—-standardized uptake value; $\mathrm{w}$-weeks.

\subsubsection{Indications}

The combination of targeted drugs with neoadjuvant RT or targeted therapy alone should be used in prospective clinical trials or individually in selected patients [7].

\subsubsection{Risks}

Potential toxicity of neoadjuvant targeted therapy with or without RT in STS is poorly investigated, thus unexpected early or late toxicities may occur. For example, the combination of CFRT with sunitinib or pazopanib leads to a high proportion of patients who experienced grade 3 or higher hepatotoxicity $[86,92]$. 


\subsection{Nanoparticles}

\subsubsection{Considerations and Available Evidence}

Various radiosensitizers were tested in clinical trials in the past, mostly in head and neck cancers [93]. However, none of them is widely used in clinical practice. In recent times, in a phase II/III multicenter, international randomized clinical trial, the authors assessed the efficacy of hafnium oxide nanoparticle (NBTXR3) as a local radiosensitizer added to neoadjuvant CFRT (2 Gy to 50 Gy, 25 fractions, five weeks) [8]. The treatment was offered to patients with locally advanced resectable STS of extremities or trunk wall. In the study group patients received a single intratumoral injection of NBTXR3 before CFRT, whereas in the control group, patients received the same CFRT alone. The primary endpoint of the study was the proportion of patients with a complete pathological response.

After enrollment, randomization, and exclusion of ineligible patients, 176 patients were analyzed. Among them, 87 were in the study group and 89 in the control group. Pathological complete response was observed in 14 patients in the study group and seven patients in the control group $(p=0.044)$. Statistically significant differences were found in the proportion of patients with R0 resection, which was more frequent in the NBTXR3 group than in the CFRT-alone group. Grade 3+ CFRT-related toxicity occurred in five patients from the study group and four patients from the control group. Grade $3+$ NBTXR3-related toxicity was observed in eight patients, i.e., post-injection pain in four cases and hypotension in six cases. Serious adverse events were noted in 35 patients who received NBTXR3 and 27 patients who received CFRT alone. The most frequent serious adverse event related to RT was postoperative wound complication.

To sum up, the NBTXR3 injection before neoadjuvant CFRT resulted in a higher proportion of patients with a pathologically complete response with no increase in RT-related toxicity and is a promising radioenhancer in further clinical applications. There is a lack of long-term outcomes of such treatment; thus, the real effectiveness of nanoparticles+RT in STS and the late toxicity profile are still unknown.

\subsubsection{Indications}

In the case of approval, the nanoparticles could be used in most patients with localized advanced STS who are eligible for intratumoral injection. In the study mentioned above, patients with STS localized in the anterior abdominal region and those with a tumor volume over $3000 \mathrm{~mL}$ were excluded [8]. The authors explained that in the case of tumors $>3000 \mathrm{~mL}$, the injection of NBTXR3 would probably be unfeasible.

\subsubsection{Risks}

The injection of nanoparticles may cause anxiety, pain, or infection within the treated site. Pain could be managed with adequate analgesia. The authors of the NBTXR3 trial reported no grade 3+ acute allergic reactions. Nevertheless, premedication with glucocorticoids should be considered before injection. There are still no data about late toxicity.

\subsection{Hyperthermia}

\subsubsection{Considerations and Available Evidence}

The term "hyperthermia" describes a variety of methods of controlled heat delivery to cancer cells. Local or regional HT is used in conjunction with RT or CHT as a potent radio- or chemo-sensitizer [94,95]. It damages cancer cells by a direct cytotoxic effect and also provides indirect additional molecular effects, such as better tissue oxygenation, induction of apoptosis, instability of the cell membrane, dysfunction of intracellular proteins, and impairment of DNA repair [96]. Preclinical studies have confirmed this effect [97-99]. Routine use is limited by the low number of phase III clinical trials and poor availability of HT equipment. 
In a phase III randomized multicenter clinical trial organized by the European Society for Hyperthermic Oncology and the EORTC-STBSG, the authors analyzed a group of 341 patients with localized high-risk STS [4]. The patients were randomly assigned into two arms. In the study arm, 169 patients received neoadjuvant CHT with etoposide, ifosfamide, and doxorubicin (EIA) concurrently with regional HT; in the control arm, 172 patients received EIA alone. The primary endpoint of the study was local progression-free survival. Local progression or death occurred more frequently in the control arm than in the study arm (relative hazard $0.58,95 \%$ CI $0.41-0.83 ; p=0.003$ ). In the HT+EIA arm, the treatment response rate was significantly higher (28.8\%) than in the EIA alone arm $(12.7 \%$, $p=0.002$ ). Among patients who completed the whole treatment, OS was better in the study group (HR $0.66,95 \%$ CI $0.45-0.98, p=0.038$ ). The main HT-related toxicities were pain, bolus pressure, and skin burn; the majority were mild or moderate.

After a median of 11.3 years of follow-up, patients from the HT+EIA arm maintained the benefit from HT [5]. In comparison to patients who received EIA alone, patients from HT+EIA had significantly better local progression-free survival (HR $0.65 ; 95 \% \mathrm{CI}, 0.49-0.86 ; p=0.002)$, survival rate (HR, 0.73 ; $95 \%$ CI, $0.54-0.98 ; p=0.04)$, 5-year survival $(62.7 \%$ vs $51.3 \%)$ and 10 -year survival $(52.6 \%$ vs. $42.7 \%)$.

In contrast, the effectiveness of HT+CHT in neoadjuvant treatment of locally advanced STS was proven in a phase III randomized clinical trial; evidence on HT+RT in STS treatment remains scarce. The toxicity and outcomes of neoadjuvant HT+HFRT (3.25 Gy to $32.5 \mathrm{~Gy}$, ten fractions, two weeks, $4 \times$ HT) are validated in a prospective phase II clinical trial SINDIR, NCT03989596 [100].

A particularly challenging situation is reirradiation due to STS relapse or radiation-induced STS. HT might be added to enhance tumor response to RT, whose dose is limited by previous RT [101-103]. In a retrospective analysis, the authors assessed the outcomes of 16 patients with radiation-induced STS in the thoracic region treated with HT+HFRT using two moderately hypofractionated regimens (3 Gy to 36 Gy, 12 fractions, three weeks, 6× HT; or 4 Gy to 32 Gy, eight fractions, two weeks, $4 \times$ HT) [6]. In 13 patients, the treatment was applied with definitive intent; in three patients, it was used as adjuvant therapy to surgery. The complete response and partial response were observed in seven and two patients, respectively. The early toxicity of HT+HFRT was good. Late toxicity occurred in seven patients but was severe in only one case, i.e., ischemia of the arm on the treated side that required forearm amputation. Currently, there is one phase II clinical trial, NCT04398095, aimed at assessing the tolerance of HT+HFRT as definitive or neoadjuvant treatment for radiation-induced or recurrent previously irradiated STS [104].

What is important, HT should not be given with each fraction to avoid a reversible phenomenon called thermotolerance [105]. Cancer cells become resistant to heat-induced damage, probably due to the synthesis of heat-shock proteins and other molecular adaptation processes if heat is applied too frequently [96]. In turn, in a phase II clinical trial, the pathological response after HT+RT was better in patients who received HT twice a week than in those who received HT once a week [106].

\subsubsection{Indications}

ESMO guidelines state that HT could be a supplementary modality to CHT [31]. Thus, HT may be offered to patients who are candidates for neoadjuvant CHT. Neoadjuvant HT+RT could be useful in patients with locally advanced STS who are not candidates for neoadjuvant systemic treatment due to poor performance status, chemoresistant pathology, or disease progression on CHT. HT+RT may also be beneficial in a selected group of patients with previously irradiated recurrent or radiation-induced STS; however, extreme caution must be taken due to the high risk of potentially severe toxicity [107]. There are no convincing data regarding optimal RT fractionation. Concurrent HT is usually applied twice a week. Treatments should be separated by at least $48 \mathrm{~h}$.

\subsubsection{Risks}

The tolerance of HT is usually excellent. Side effects are mild and include pain at the target site, blisters, skin damage, erythema, bleeding, thrombosis, infection, edema, and neuropathy [99,108]. 
In the case of deep regional HT, additionally, some general symptoms may occur, such as nausea, vomiting, or dyspnea. The late toxicity of HT is poorly investigated. HT should not be used for pregnant or breastfeeding women [109]. Other contraindications include the presence of metal implants or pacemakers within or in the proximity of heated tissues, unstable cardiovascular disease, epilepsy, significant neuropathy with a deteriorated sense of temperature, significant fever, or a large fluid compartment within the tumor [110].

\section{Response Assessment}

\subsection{Radiological}

A standardized approach of radiological response evaluation is crucial for a single patient who undergoes neoadjuvant treatment as well as for scientific purposes when a new regimen is assessed. Intratumoral environment variability of STS can lead to several pathological changes after neoadjuvant treatment, namely edema, hemorrhage, and necrosis, that might increase tumor volume and be wrongly misinterpreted as disease progression [75]. The analysis of 99 patients with STS treated with neoadjuvant or palliative RT has shown that in 58 patients, the tumor volume changed significantly with a volume increase in the majority of cases [111]. Moreover, a decrease in tumor size may be correlated with the presence of viable sarcoma cells, whereas "pseudoprogressing" tumors might be related to an extensive pathological response $[79,112]$. Thus, conventional response evaluation criteria in solid tumors (RECIST 1.1) should not be used to assess the response to neoadjuvant treatment in STS, except for myxoid liposarcomas.

EORTC-STBSG published guidelines on radiological examination and reporting after neoadjuvant RT in STS [113]. The emphasis is placed on MRI before and after RT as a suggested modality in response assessment. The article gives recommendations regarding the optimal timing and protocol of MRI. It is recommended that:

Post-RT imaging should not be performed earlier than four weeks post-RT (later if possible);

Images acquired in the same plane should be performed with identical planing and slice thickness to allow correlation between sequences;

Except for myxoid liposarcomas, size and volume measurements should not be used to reflect histopathological response;

Internal signal/density characteristics should be used in combination to assess response;

Areas of new enhancement should be interpreted with caution as they can arise secondarily to vascular disruption following RT and do not necessarily reflect progression;

Not all areas of diminished enhancement following RT represent necrosis and, therefore, attention to terminology is suggested. The term "treatment effects" may be more appropriate encompassing several processes, such as necrosis, cystic change (liquefaction), or hyalinization.

Special attention was paid to functional imaging. The authors gave recommendations regarding parameters for reporting multiparametric MRI in clinical trials.

\subsection{Pathological}

Treatment-induced tissue necrosis is a predictive factor of patient survival in bone sarcomas. Several attempts failed to show this dependency in STS [114,115]. At the same time, meta-analysis of 21 studies comprising 1663 patients has confirmed that tumor necrosis $<90 \%$ following neoadjuvant therapy in STS is associated with increased recurrence risk and shorter OS [116].

For pathology reports, several pathological factors were considered in various studies until the proposal of a standardized pathological examination and reporting of STS resection material after neoadjuvant treatment was published by EORTC-STBSG [117]. The article describes the process of specimen documentation. The most important innovation is the introduction of the five-grade scale of microscopic evaluation based on the proportion of tumor area that is viable. The assessment is based on "stainability," which means the visualization of nuclei by hematoxylin. The percentage of stainable 
cells should represent the whole specimen; thus, the representative slab should be supplemented with additional blocks in the final response score. The categories include:

A: no stainable tumor cells;

B: single stainable tumor cells or small clusters (overall below $1 \%$ of the whole specimen);

C: $>=1 \%-<10 \%$ stainable tumor cells;

D: $>=10 \%-<50 \%$ stainable tumor cells;

E: $>=50 \%$ stainable tumor cells.

The authors were not able to give any recommendations regarding immunohistochemical markers that may be useful in the assessment of pathological response.

\subsection{Biomarkers}

There are as of yet no specific biomarkers that would predict patient survival or, even better, indicate the optimal type of therapy. The general importance of using proper markers has been pointed out by Mortaji and Lebduska [118]. Kondo and Kawai suggested investigating (for STS) numerous potentially useful molecular proteomic markers which have contributed to cancer therapy, but they did not follow up on their suggestions [119]. However, in 2019 Burns et al. stated that no proteomic markers for STS had reached the clinic [120]. Kane et al. examined specimens from 60 STS patients, but pretreatment samples were available for only 23 and matched samples pre- and post-treatment for 12 [121]. They analyzed the expression of several genes involved in cell-cycle regulation and hypoxia but did not find (possibly because of the small size of the group) any association of pretreatment expression of any of the markers with survival.

Schenone and Van Tine have identified seven biomarkers potentially useful for therapies commonly used in STS treatment (except for gastrointestinal stromal tumors) [122]. These are TOP2A (topoisomerase IIA for anthracycline), RRM1 (ribonucleotide reductase M1 unit for gemcitabine and Taxotere), TLE3 (transducing-like enhancer protein 3 for taxanes), MGMT (O6-methylguanine-DNA-transferase for temozolomide and dacarbazine), TUBB3 (tubulin beta-3 chain for taxanes and vinca alkaloids), SPARC (secreted protein acidic and rich in cysteine for taxanes) and PTEN (phosphatidylinositol-3,4,5-triphosphate 3-phosphatase for mTOR inhibitors), and the authors have carefully analyzed earlier studies; however, most of them did not concern STS.

More recently, Caruso and Garofalo analyzed pharmacogenomic biomarkers for STS therapies [123]. These biomarkers would be potentially useful in predicting drug responses in patients. They have analyzed the literature for germline and somatic biomarkers and suggest that next-generation sequencing technologies and larger gene panels would be useful in obtaining results that could be implemented in the clinic.

In the clinical trial NCT01710176, Pasquali et al. used a 67-gene expression-based signature to stratify 87 patients into lower-risk and higher-risk groups; however, no differences were observed between them in disease-free and OS, even though this set of markers, CINSARC (complexity index in sarcomas) had been previously tested in retrospective studies [124]. Other STS biomarker clinical studies are ongoing.

\section{Novel Approaches and Future Directions}

\subsection{Molecular Targeted Therapy}

The only routinely used highly effective neoadjuvant subtype-targeted therapy in STS is imatinib for unresectable localized dermatofibrosarcoma protuberans and gastrointestinal stromal tumors [125,126]. However, being a diversified and orphan group of tumors, STS present various genetic alterations that may be potential targets for novel targeted therapies. Possible genetic pathways include specific translocations (for example, anaplastic lymphoma kinase [ALK] fusion in inflammatory myofibroblastic tumors), gene amplifications (for example, the amplification of $M Y C$ in 
radiation-induced angiosarcomas), oncogenic mutations (for example, activating mutations in the KIT receptor), and complex genomic rearrangements (vast majority of STS) [127]. A clear example is an inhibitor of enhancer of zeste homolog 2 ( $E Z H 2$ ) histone methyltransferase, tazemetostat, registered in the USA for metastatic or locally advanced unresectable epithelioid sarcoma [128]. A mutation in the INI1 suppressor gene in epithelioid sarcoma cells causes deregulation of EZH2 that leads to the activation of multiple oncogenic signaling pathways. Tazemetostat competitively inhibits $E Z H 2$, stopping epithelioid sarcoma growth. Another effective novel therapy, namely the inhibitor of tropomyosin receptor kinases A, B and C, targets NTRK fusions. An analysis of databases from three ongoing phase I or II clinical trials with entrectinib (ALKA-372-001, STARTRK-1, and STARTRK-2), which enrolled 54 patients with metastatic or locally advanced NTRK fusion-positive solid tumors, showed a high ratio of objective durable responses (31/54 patients, median duration 10 months) with good treatment tolerance [129]. In the study, STS were the predominant group of tumors (13 patients, $24 \%)$. The objective response was observed in almost half of them (6/13 patients, $46 \%)$. Several other subtype-targeted molecules are currently under investigation $[127,130,131]$.

\subsection{Immunotherapy}

Promising results of immune checkpoint inhibitors in various cancers encouraged investigators to assess their potential in STS. This group of molecules targets the most important regulators of the immune system that are responsible for anticancer response. Immune checkpoint inhibitors are especially active in tumors with a high mutational burden. Approved molecules include anti-CTLA4, anti-programmed cell death 1 (PD-1), and anti-PD-1 ligand immunotherapies. Despite a strong theoretical basis and expectations, preliminary results from phase I and II clinical trials showed moderate activity of immunotherapy in STS [132]. The exception is alveolar soft part tissue sarcoma, a rare and radiochemoresistant STS subtype. In a phase II clinical trial with axitinib and pembrolizumab in patients with advanced alveolar soft part tissue sarcomas and other STS subtypes, the 6- and 12 -months progression-free survivals were $47 \%$ and $28 \%$, respectively [133]. The best overall response rate was described in eight patients and, among them, six had alveolar soft part tissue sarcoma. Another report described similar activity of immunotherapy in this rare STS subtype [134]. Nevertheless, immunotherapy has not been investigated in nonmetastatic or resectable STS. Thus, it should not be recommended as a neoadjuvant treatment. New clinical trials are required to assess the efficacy of immunotherapy in STS.

\section{Practical Recommendations and Conclusions}

\subsection{Particular Clinical Situations}

\subsubsection{High Risk Soft Tissue Sarcomas}

Patients with high-risk STS may benefit from neoadjuvant therapy. Neoadjuvant RT should be a part of the treatment provided that a risk of wound complications is acceptable. Due to high risk of distant metastases, RT may be combined with neoadjuvant CHT. Anthracycline-ifosfamide CHT regimens are preferred regardless of STS subtype. In fragile patients, less intensive CHT regimens, such as anthracyclines alone, may provide adequate efficacy without the risk of a significant increase in CHT toxicity.

\subsubsection{Locally Advanced Low-Grade Soft Tissue Sarcomas}

Slowly growing locally advanced low-grade tumors bring a low risk of metastatic spread. Thus, administration of CHT is not recommended. This group of STS is relatively more radioresistant. Therefore, based on radiobiological models, hypofractionated RT might provide benefit in local response. Additional radiosensitizing modalities such as HT may enhance efficacy of RT. 


\subsubsection{Marginally Resectable or Non-Resectable Soft Tissue Sarcomas}

Neoadjuvant therapy is the gold standard for the treatment of marginally resectable or non-resectable STS. Both CRFT and HFRT may be considered. In bulky, symptomatic tumors, shorter RT regimens are preferred. RT might be combined with anthracycline-based CHT to increase local response and decrease the risk of distant metastases. Due to the usually large volume of those tumors and related symptoms, the application of regional HT or nanoparticles may be problematic or even unfeasible.

\subsubsection{Chemoresistant Sarcoma Subtypes}

Epithelioid sarcoma, extraskeletal myxoid chondrosarcoma, clear cell sarcoma, solitary fibrous tumor, alveolar soft part sarcoma and inflammatory myofibroblastic tumor constitute STS subtypes resistant to conventional cytotoxic chemotherapy. In those subtypes, neoadjuvant CHT is not recommended due to lack of efficacy and risk of disease progression. In the case of resectable chemoresistant STS, the preferred neoadjuvant approach is RT followed by surgery. More locally advanced and marginally resectable chemoresistant STS may benefit from additional radiosensitizing modalities, such as HT or nanoparticles. Although no targeted therapies have been investigated as a neoadjuvant treatment specifically in chemoresistant STS, tyrosine kinase inhibitors and antiangiogenic agents may be considered individually in selected cases. The only exception is the inflammatory myofibroblastic tumor presenting the ALK gene mutation, which is susceptible to ALK inhibitors [135].

\subsubsection{Radiation-Induced or In-Field Recurrent Soft Tissue Sarcomas}

The management of radiation-induced or in-field recurrent STS is challenging. The only curative modality in localized tumors is radical resection with wide negative margins. The role of secondary RT is unclear, mostly due to the concerns about possible severe side effects after re-irradiation. However, RT may be carefully considered in selected cases, especially after a long period from the first RT, and absence of significant late toxicity from previous irradiation. HT may allow RT dose reduction without a decrease in treatment efficacy. CHT and targeted therapy may be used in metastatic disease, but their role in neoadjuvant therapy is not established.

\subsection{Conclusions}

There are multiple options for neoadjuvant treatment in STS that are focused on improving local and distant control. Any neoadjuvant approach should be considered individually at the MTB, taking into consideration tumor site, stage, pathology, comorbidities, age, resectability, institutional protocols, and availability of methods. The authors' consensus on available combinations that could be considered in various clinical situations is presented in Table 5. The response to treatment should be assessed by standardized radiological and pathological criteria. New clinical trials with new combinations of methods in the neoadjuvant setting are encouraged. 
Table 5. Combinations of neoadjuvant treatment in soft tissue sarcomas in various clinical situations: authors' consensus.

\begin{tabular}{|c|c|c|}
\hline $\begin{array}{c}\text { Clinical Situation with Localized } \\
\text { Soft Tissue Sarcoma }\end{array}$ & $\begin{array}{c}\text { Recommended Neoadjuvant } \\
\text { Therapy }\end{array}$ & Methods not Recommended \\
\hline High risk & $\begin{array}{c}\text { Radiotherapy } \\
\text { Chemotherapy } \\
\text { Radiotherapy + chemotherapy } \\
\text { Chemotherapy + hyperthermia }\end{array}$ & - \\
\hline Locally advanced low-grade & $\begin{array}{c}\text { Radiotherapy }^{1} \\
\text { Radiotherapy }^{1}+\text { hyperthermia }^{2}\end{array}$ & Chemotherapy \\
\hline $\begin{array}{l}\text { Marginally resectable and } \\
\text { non-resectable }\end{array}$ & $\begin{array}{c}\text { Radiotherapy }{ }^{1}+\text { chemotherapy } \\
\text { Radiotherapy }{ }^{1}\end{array}$ & Hyperthermia $^{3}$ \\
\hline Chemoresistant subtypes & $\begin{array}{c}\text { Radiotherapy } \\
\text { Radiotherapy + hyperthermia }{ }^{2} \\
\text { Radiotherapy }+ \text { targeted therapy }{ }^{2} \\
\text { Targeted therapy } 2,4\end{array}$ & Chemotherapy \\
\hline $\begin{array}{l}\text { Radiation induced or in-field } \\
\text { recurrent }\end{array}$ & $\begin{array}{c}\text { Chemotherapy } \\
\text { Chemotherapy + hyperthermia } \\
\text { Radiotherapy + hyperthermia }{ }^{2} \\
\text { Radiotherapy }\end{array}$ & $\begin{array}{l}\text { Radiotherapy in case of early } \\
\text { recurrence or significant late } \\
\text { toxicity }\end{array}$ \\
\hline
\end{tabular}

${ }^{1}$ Hypofractionated regimens should be considered; ${ }^{2}$ Experimental (clinical trials); ${ }^{3}$ unfeasible in most cases; ${ }^{4}$ routinely only in dermatofibrosarcoma protuberans.

Author Contributions: Conceptualization, M.J.S. and K.K.; methodology, M.J.S.; validation, A.M.C., A.B., and E.B.; investigation, M.J.S. and K.K.; resources, M.J.S., K.K., E.B.; writing-original draft preparation, M.J.S.; writing-review and editing, K.K., A.M.C., E.B., A.B.; visualization, M.S, and K.K.; supervision, P.R.; project administration, M.J.S. All authors have read and agreed to the published version of the manuscript.

Funding: This research received no external funding. The processing charges cost was covered by the Maria Sklodowska-Curie National Research Institute of Oncology, Warsaw, Poland.

Conflicts of Interest: M.J.S., A.B., and P.R. declare personal fees from Nanobiotix during the conduct of the study with NBTXR3 (NCT02379845), outside the submitted work. P.R. reports personal fees from Novartis, BMS, MSD, Roche, Amgen, Eli Lilly, Pfizer, and Blueprint Medicines, outside the submitted work. M.J.S. declares personal fees from Novartis, outside the submitted work. A.M.C. reports personal fees from Novartis, BMS, MSD, outside the submitted work. K.K. reports personal fees from BMS, MSD, Novartis, Pfizer and Roche, outside the submitted work.

\section{References}

1. Yang, J.C.; Chang, A.E.; Baker, A.R.; Sindelar, W.F.; Danforth, D.N.; Topalian, S.L.; DeLaney, T.; Glatstein, E.; Steinberg, S.M.; Merino, M.J.; et al. Randomized prospective study of the benefit of adjuvant radiation therapy in the treatment of soft tissue sarcomas of the extremity. J. Clin. Oncol. 1998, 16, 197-203. [CrossRef] [PubMed]

2. Gronchi, A.; Ferrari, S.; Quagliuolo, V.; Broto, J.M.; Lopez-Pousa, A.; Grignani, G.; Ferraresi, V.; Blay, J.-Y.; Rutkowski, P.; Merlo, F.D.; et al. sarcoma Full-dose neoadjuvant anthracycline + ifosfamide chemotherapy is associated with a relapse free survival (RFS) and overall survival (OS) benefit in localized high-risk adult soft tissue sarcomas (STS) of the extremities and trunk wall: Interim analysis of a prospective randomized trial. Ann. Oncol. 2016, 27, 587. [CrossRef]

3. Lindner, L.H.; Issels, R.D. Hyperthermia in soft tissue sarcoma. Curr. Treat. Options Oncol. 2011, 12, 12-20. [CrossRef] [PubMed]

4. Issels, R.D.; Lindner, L.H.; Verweij, J.; Wust, P.; Reichardt, P.; Schem, B.-C.; Abdel-Rahman, S.; Daugaard, S.; Salat, C.; Wendtner, C.-M.; et al. Neo-adjuvant chemotherapy alone or with regional hyperthermia for localised high-risk soft-tissue sarcoma: A randomised phase 3 multicentre study. Lancet Oncol. 2010, 11, 561-570. [CrossRef] 
5. Issels, R.D.; Lindner, L.H.; Verweij, J.; Wessalowski, R.; Reichardt, P.; Wust, P.; Ghadjar, P.; Hohenberger, P.; Angele, M.; Salat, C.; et al. Effect of Neoadjuvant Chemotherapy Plus Regional Hyperthermia on Long-term Outcomes Among Patients with Localized High-Risk Soft Tissue Sarcoma: The EORTC 62961-ESHO 95 Randomized Clinical Trial. JAMA Oncol. 2018, 4, 483-492. [CrossRef]

6. De Jong, M.A.A.; Oldenborg, S.; Bing Oei, S.; Griesdoorn, V.; Kolff, M.W.; Koning, C.C.E.; Van Tienhoven, G. Reirradiation and hyperthermia for radiation-associated sarcoma. Cancer 2012, 118, 180-187. [CrossRef]

7. Haas, R.L.M.; Miah, A.B.; LePechoux, C.; DeLaney, T.F.; Baldini, E.H.; Alektiar, K.; O’Sullivan, B. Preoperative radiotherapy for extremity soft tissue sarcoma; past, present and future perspectives on dose fractionation regimens and combined modality strategies. Radiother. Oncol. 2016, 119, 14-21. [CrossRef]

8. Bonvalot, S.; Rutkowski, P.L.; Thariat, J.; Carrère, S.; Ducassou, A.; Sunyach, M.-P.; Agoston, P.; Hong, A.; Mervoyer, A.; Rastrelli, M.; et al. NBTXR3, a first-in-class radioenhancer hafnium oxide nanoparticle, plus radiotherapy versus radiotherapy alone in patients with locally advanced soft-tissue sarcoma (Act.In.Sarc): A multicentre, phase 2-3, randomised, controlled trial. Lancet Oncol. 2019, 20, 1148-1159. [CrossRef]

9. Haas, R.L. Preoperative radiotherapy in soft tissue sarcoma: From general guidelines to personalized medicine. Chin. Clin. Oncol. 2018, 7, 8. [CrossRef] [PubMed]

10. O'Sullivan, B.; Davis, A.; Turcotte, R.; Bell, R.; Wunder, J.; Catton, C.; Kandel, R.; Sadura, A.; Tu, D.; Pater, J. Five-year results of a randomized phase III trial of pre-operative vs post-operative radiotherapy in extremity soft tissue sarcoma. J. Clin. Oncol. 2004, 22, 9007. [CrossRef]

11. O'Sullivan, B.; Davis, A.M.; Turcotte, R.; Bell, R.; Catton, C.; Chabot, P.; Wunder, J.; Kandel, R.; Goddard, K.; Sadura, A.; et al. Preoperative versus postoperative radiotherapy in soft-tissue sarcoma of the limbs: A randomised trial. Lancet 2002, 359, 2235-2241. [CrossRef]

12. RTOG $>$ Core Lab > Contouring Atlases $>$ RTOG Extremity Soft Tissue Sarcoma Atlas. Available online: https://www.rtog.org/CoreLab/ContouringAtlases/RTOGExtremitySoftTissueSarcomaAtlas.aspx (accessed on 20 June 2020).

13. Wang, D.; Zhang, Q.; Eisenberg, B.L.; Kane, J.M.; Li, X.A.; Lucas, D.; Petersen, I.A.; DeLaney, T.F.; Freeman, C.R.; Finkelstein, S.E.; et al. Significant Reduction of Late Toxicities in Patients With Extremity Sarcoma Treated With Image-Guided Radiation Therapy to a Reduced Target Volume: Results of Radiation Therapy Oncology Group RTOG-0630 Trial. J. Clin. Oncol. 2015, 33, 2231-2238. [CrossRef] [PubMed]

14. Jang, S.Y.; Liu, H.H.; Mohan, R. Underestimation of low-dose radiation in treatment planning of intensity-modulated radiotherapy. Int. J. Radiat. Oncol. Biol. Phys. 2008, 71, 1537-1546. [CrossRef] [PubMed]

15. O'Sullivan, B.; Griffin, A.M.; Dickie, C.I.; Sharpe, M.B.; Chung, P.W.M.; Catton, C.N.; Ferguson, P.C.; Wunder, J.S.; Deheshi, B.M.; White, L.M.; et al. Phase 2 study of preoperative image-guided intensity-modulated radiation therapy to reduce wound and combined modality morbidities in lower extremity soft tissue sarcoma. Cancer 2013, 119, 1878-1884. [CrossRef]

16. Peeken, J.C.; Knie, C.; Kessel, K.A.; Habermehl, D.; Kampfer, S.; Dapper, H.; Devecka, M.; Von Eisenhart-Rothe, R.; Specht, K.; Weichert, W.; et al. Neoadjuvant image-guided helical intensity modulated radiotherapy of extremity sarcomas-A single center experience. Radiat. Oncol. 2019, 14, 2. [CrossRef] [PubMed]

17. Haas, R.L.M.; Delaney, T.F.; O’Sullivan, B.; Keus, R.B.; Le Pechoux, C.; Olmi, P.; Poulsen, J.-P.; Seddon, B.; Wang, D. Radiotherapy for management of extremity soft tissue sarcomas: Why, when, and where? Int. J. Radiat. Oncol. Biol. Phys. 2012, 84, 572-580. [CrossRef]

18. Spałek, M.J.; Rutkowski, P. Coronavirus Disease (COVID-19) Outbreak: Hypofractionated Radiotherapy in Soft Tissue Sarcomas as a Valuable Option in the Environment of Limited Medical Resources and Demands for Increased Protection of Patients. Front. Oncol. 2020, 10. [CrossRef]

19. Stragliotto, C.L.; Karlsson, K.; Lax, I.; Rutkowska, E.; Bergh, J.; Strander, H.; Blomgren, H.; Friesland, S. A retrospective study of SBRT of metastases in patients with primary sarcoma. Med. Oncol. 2012, 29, 3431-3439. [CrossRef]

20. Ritter, M. Rationale, conduct, and outcome using hypofractionated radiotherapy in prostate cancer. Semin. Radiat. Oncol. 2008, 18, 249-256. [CrossRef]

21. Hegemann, N.-S.; Guckenberger, M.; Belka, C.; Ganswindt, U.; Manapov, F.; Li, M. Hypofractionated radiotherapy for prostate cancer. Radiat. Oncol. 2014, 9, 275. [CrossRef] 
22. Benjamin, L.C.; Tree, A.C.; Dearnaley, D.P. The Role of Hypofractionated Radiotherapy in Prostate Cancer. Curr. Oncol. Rep. 2017, 19, 30. [CrossRef]

23. Moore, A.; Den, R.B.; Gordon, N.; Sarfaty, M.; Kundel, Y.; Brenner, B.; Goldstein, D.A. The Financial Impact of Fractionation Scheme and Treatment Planning Method for Rectal Cancer in the United States. Clin. Colorectal Cancer 2019, 18, 209-217. [CrossRef]

24. Wang, S.; Wen, F.; Zhang, P.; Wang, X.; Li, Q. Cost-effectiveness analysis of long-course oxaliplatin and bolus of fluorouracil based preoperative chemoradiotherapy vs. 5x5Gy radiation plus FOLFOX4 for locally advanced resectable rectal cancer. Radiat. Oncol. 2019, 14, 113. [CrossRef] [PubMed]

25. O'Donnell, P.W.; Griffin, A.M.; Eward, W.C.; Sternheim, A.; Catton, C.N.; Chung, P.W.; O'Sullivan, B.; Ferguson, P.C.; Wunder, J.S. The effect of the setting of a positive surgical margin in soft tissue sarcoma. Cancer 2014, 120, 2866-2875. [CrossRef] [PubMed]

26. Al Yami, A.; Griffin, A.M.; Ferguson, P.C.; Catton, C.N.; Chung, P.W.M.; Bell, R.S.; Wunder, J.S.; O'Sullivan, B. Positive surgical margins in soft tissue sarcoma treated with preoperative radiation: Is a postoperative boost necessary? Int. J. Radiat. Oncol. Biol. Phys. 2010, 77, 1191-1197. [CrossRef] [PubMed]

27. Pan, E.; Goldberg, S.I.; Chen, Y.-L.; Giraud, C.; Hornick, J.L.; Nielsen, G.P.; Hornicek, F.J.; Raut, C.P.; DeLaney, T.F.; Baldini, E.H. Role of post-operative radiation boost for soft tissue sarcomas with positive margins following pre-operative radiation and surgery. J. Surg. Oncol. 2014, 110, 817-822. [CrossRef]

28. Von Mehren, M.; Randall, R.L.; Benjamin, R.S.; Boles, S.; Bui, M.M.; Ganjoo, K.N.; George, S.; Gonzalez, R.J.; Heslin, M.J.; Kane, J.M.; et al. Soft Tissue Sarcoma, Version 2.2018, NCCN Clinical Practice Guidelines in Oncology. J. Natl. Compr. Cancer Netw. 2018, 16, 536-563. [CrossRef]

29. Mohiuddin, M.; Memon, M.; Nobah, A.; Elsebaie, M.; AL Suhaibani, A.; Pant, R.; Shaheen, M.; Alyamani, M.; Al Dayal, F. Locally advanced high-grade extremity soft tissue sarcoma: Response with novel approach to neoadjuvant chemoradiation using induction spatially fractionated GRID radiotherapy (SFGRT). J. Clin. Oncol. 2014, 32, 10575. [CrossRef]

30. Billena, C.; Khan, A.J. A Current Review of Spatial Fractionation: Back to the Future? Int. J. Radiat. Oncol. Biol. Phys. 2019, 104, 177-187. [CrossRef]

31. Casali, P.G.; Abecassis, N.; Aro, H.T.; Bauer, S.; Biagini, R.; Bielack, S.; Bonvalot, S.; Boukovinas, I.; Bovee, J.V.M.G.; Brodowicz, T.; et al. Soft tissue and visceral sarcomas: ESMO-EURACAN Clinical Practice Guidelines for diagnosis, treatment and follow-up. Ann. Oncol. 2018, 29, 51-67. [CrossRef]

32. Davis, A.M.; O'Sullivan, B.; Turcotte, R.; Bell, R.; Catton, C.; Chabot, P.; Wunder, J.; Hammond, A.; Benk, V.; Kandel, R.; et al. Late radiation morbidity following randomization to preoperative versus postoperative radiotherapy in extremity soft tissue sarcoma. Radiother. Oncol. 2005, 75, 48-53. [CrossRef] [PubMed]

33. Spałek, M. Chronic radiation-induced dermatitis: Challenges and solutions. Clin. Cosmet. Investig. Derm. 2016, 9, 473-482. [CrossRef]

34. Baldini, E.H.; Lapidus, M.R.; Wang, Q.; Manola, J.; Orgill, D.P.; Pomahac, B.; Marcus, K.J.; Bertagnolli, M.M.; Devlin, P.M.; George, S.; et al. Predictors for major wound complications following preoperative radiotherapy and surgery for soft-tissue sarcoma of the extremities and trunk: Importance of tumor proximity to skin surface. Ann. Surg. Oncol. 2013, 20, 1494-1499. [CrossRef] [PubMed]

35. Schwartz, A.; Rebecca, A.; Smith, A.; Casey, W.; Ashman, J.; Gunderson, L.; Curtis, K.; Chang, Y.-H.H.; Beauchamp, C. Risk factors for significant wound complications following wide resection of extremity soft tissue sarcomas. Clin. Orthop. Relat. Res. 2013, 471, 3612-3617. [CrossRef] [PubMed]

36. Korah, M.P.; Deyrup, A.T.; Monson, D.K.; Oskouei, S.V.; Weiss, S.W.; Landry, J.; Godette, K.D. Anatomic tumor location influences the success of contemporary limb-sparing surgery and radiation among adults with soft tissue sarcomas of the extremities. Int. J. Radiat. Oncol. Biol. Phys. 2012, 82, 933-939. [CrossRef] [PubMed]

37. Blay, J.-Y.; Le Cesne, A. Adjuvant chemotherapy in localized soft tissue sarcomas: Still not proven. Oncologist 2009, 14, 1013-1020. [CrossRef]

38. Loong, H.H.; Wong, K.-H.; Tse, T. Controversies and consensus of neoadjuvant chemotherapy in soft-tissue sarcomas. ESMO Open 2018, 3, e000293. [CrossRef] [PubMed]

39. Rutkowski, P. Local Treatment After Neo-Adjuvant Therapy. Ann. Oncol. 2014, 25, 31. [CrossRef]

40. Baldini, E.H.; Le Cesne, A.; Trent, J.C. Neoadjuvant Chemotherapy, Concurrent Chemoradiation, and Adjuvant Chemotherapy for High-Risk Extremity Soft Tissue Sarcoma. Am. Soc. Clin. Oncol. Educ. Book 2018, 38, 910-915. [CrossRef] 
41. Dangoor, A.; Seddon, B.; Gerrand, C.; Grimer, R.; Whelan, J.; Judson, I. UK guidelines for the management of soft tissue sarcomas. Clin. Sarcoma Res. 2016, 6, 20. [CrossRef]

42. Pervaiz, N.; Colterjohn, N.; Farrokhyar, F.; Tozer, R.; Figueredo, A.; Ghert, M. A systematic meta-analysis of randomized controlled trials of adjuvant chemotherapy for localized resectable soft-tissue sarcoma. Cancer 2008, 113, 573-581. [CrossRef] [PubMed]

43. Eilber, F.C.; Rosen, G.; Eckardt, J.; Forscher, C.; Nelson, S.D.; Selch, M.; Dorey, F.; Eilber, F.R. Treatment-induced pathologic necrosis: A predictor of local recurrence and survival in patients receiving neoadjuvant therapy for high-grade extremity soft tissue sarcomas. J. Clin. Oncol. 2001, 19, 3203-3209. [CrossRef]

44. Grobmyer, S.R.; Maki, R.G.; Demetri, G.D.; Mazumdar, M.; Riedel, E.; Brennan, M.F.; Singer, S. Neo-adjuvant chemotherapy for primary high-grade extremity soft tissue sarcoma. Ann. Oncol. 2004, 15, 1667-1672. [CrossRef]

45. Italiano, A.; Penel, N.; Robin, Y.-M.; Bui, B.; Le Cesne, A.; Piperno-Neumann, S.; Tubiana-Hulin, M.; Bompas, E.; Chevreau, C.; Isambert, N.; et al. Neo/adjuvant chemotherapy does not improve outcome in resected primary synovial sarcoma: A study of the French Sarcoma Group. Ann. Oncol. 2009, 20, 425-430. [CrossRef] [PubMed]

46. Woll, P.J.; Reichardt, P.; Le Cesne, A.; Bonvalot, S.; Azzarelli, A.; Hoekstra, H.J.; Leahy, M.; Van Coevorden, F.; Verweij, J.; Hogendoorn, P.C.W.; et al. Adjuvant chemotherapy with doxorubicin, ifosfamide, and lenograstim for resected soft-tissue sarcoma (EORTC 62931): A multicentre randomised controlled trial. Lancet Oncol. 2012, 13, 1045-1054. [CrossRef]

47. Gortzak, E.; Azzarelli, A.; Buesa, J.; Bramwell, V.H.; Van Coevorden, F.; Van Geel, A.N.; Ezzat, A.; Santoro, A.; Oosterhuis, J.W.; Van Glabbeke, M.; et al. A randomised phase II study on neo-adjuvant chemotherapy for "high-risk" adult soft-tissue sarcoma. Eur. J. Cancer 2001, 37, 1096-1103. [CrossRef]

48. Pasquali, S.; Gronchi, A. Neoadjuvant chemotherapy in soft tissue sarcomas: Latest evidence and clinical implications. Adv. Med. Oncol. 2017, 9, 415-429. [CrossRef]

49. Gronchi, A.; Palmerini, E.; Quagliuolo, V.; Martin Broto, J.; Lopez Pousa, A.; Grignani, G.; Brunello, A.; Blay, J.-Y.; Tendero, O.; Diaz Beveridge, R.; et al. Neoadjuvant Chemotherapy in High-Risk Soft Tissue Sarcomas: Final Results of a Randomized Trial From Italian (ISG), Spanish (GEIS), French (FSG), and Polish (PSG) Sarcoma Groups. J. Clin. Oncol. 2020, 38, 1903289. [CrossRef]

50. Gronchi, A.; Ferrari, S.; Quagliuolo, V.; Broto, J.M.; Pousa, A.L.; Grignani, G.; Basso, U.; Blay, J.-Y.; Tendero, O.; Beveridge, R.D.; et al. Histotype-tailored neoadjuvant chemotherapy versus standard chemotherapy in patients with high-risk soft-tissue sarcomas (ISG-STS 1001): An international, open-label, randomised, controlled, phase 3, multicentre trial. Lancet Oncol. 2017, 18, 812-822. [CrossRef]

51. Gronchi, A.; Frustaci, S.; Mercuri, M.; Martin, J.; Lopez-Pousa, A.; Verderio, P.; Mariani, L.; Valagussa, P.; Miceli, R.; Stacchiotti, S.; et al. Short, full-dose adjuvant chemotherapy in high-risk adult soft tissue sarcomas: A randomized clinical trial from the Italian Sarcoma Group and the Spanish Sarcoma Group. J. Clin. Oncol. 2012, 30, 850-856. [CrossRef]

52. Gronchi, A.; Stacchiotti, S.; Verderio, P.; Ferrari, S.; Martin Broto, J.; Lopez-Pousa, A.; Llombart-Bosch, A.; Dei Tos, A.P.; Collini, P.; Jurado, J.C.; et al. Short, full-dose adjuvant chemotherapy (CT) in high-risk adult soft tissue sarcomas (STS): Long-term follow-up of a randomized clinical trial from the Italian Sarcoma Group and the Spanish Sarcoma Group. Ann. Oncol. 2016, 27, 2283-2288. [CrossRef] [PubMed]

53. Palassini, E.; Ferrari, S.; Verderio, P.; De Paoli, A.; Martin Broto, J.; Quagliuolo, V.; Comandone, A.; Sangalli, C.; Palmerini, E.; Lopez-Pousa, A.; et al. Feasibility of Preoperative Chemotherapy With or Without Radiation Therapy in Localized Soft Tissue Sarcomas of Limbs and Superficial Trunk in the Italian Sarcoma Group/Grupo Español de Investigación en Sarcomas Randomized Clinical Trial: Three Versus Five Cycles of Full-Dose Epirubicin Plus Ifosfamide. J. Clin. Oncol. 2015, 33, 3628-3634. [CrossRef] [PubMed]

54. Pasquali, S.; Colombo, C.; Bottelli, S.; Verderio, P.; Broto, J.M.; Lopez-Pousa, A.; Ferrari, S.; Poveda, A.; Quagliolo, V.; Gronchi, A. The sarculator predicted risk of distant metastasis and overall survival in patients with high-risk soft tissue sarcoma treated with perioperative chemotherapy in a randomised controlled trial. Eur. J. Surg. Oncol. 2018, 44, e2. [CrossRef]

55. Rutkowski, R.P.; Ługowska, I. Soft tissue sarcomas in adults. Oncol. Clin. Pract. 2017, 13, 181-201. [CrossRef]

56. Aguiar Junior, S.; Ferreira, F.O.; Rossi, B.M.; Santos, É.M.M.; Salvajoli, J.V.; Lopes, A. Neoadjuvant chemoradiation therapy for soft tissue sarcomas of the extremities. Clinics 2009, 64, 1059-1064. [CrossRef] [PubMed] 
57. Spalek, M.; Koseła-Paterczyk, H.; Borkowska, A.; Wagrodzki, M.; Szumera-Ciećkiewicz, A.; Cieszanowski, A.; Castaneda-Wysocka, P.; Świtaj, T.; Dudzisz-Śledź, M.; Czarnecka, A.; et al. OC-0069 5x5 Gy with chemotherapy in borderline resectable soft tissue sarcomas: Early results of a trial. Radiother. Oncol. 2019, 133, S31-S32. [CrossRef]

58. D'Ambrosio, L.; Touati, N.; Blay, J.-Y.; Grignani, G.; Flippot, R.; Czarnecka, A.M.; Piperno-Neumann, S.; Martin-Broto, J.; Sanfilippo, R.; Katz, D.; et al. Doxorubicin plus dacarbazine, doxorubicin plus ifosfamide, or doxorubicin alone as a first-line treatment for advanced leiomyosarcoma: A propensity score matching analysis from the European Organization for Research and Treatment of Cancer Soft Tissue and Bone Sarcoma Group. Cancer 2020, 126, 2637-2647. [CrossRef]

59. Frezza, A.M.; Stacchiotti, S.; Gronchi, A. Systemic treatment in advanced soft tissue sarcoma: What is standard, what is new. BMC Med. 2017, 15, 109. [CrossRef]

60. Fairweather, M.; Keung, E.; Raut, C.P. Neoadjuvant Therapy for Soft-Tissue Sarcomas. Oncology 2016, 30, 99-106.

61. Plosker, G.L.; Faulds, D. Epirubicin: A review of its pharmacodynamic and pharmacokinetic properties, and therapeutic use in cancer chemotherapy. Drugs 1993, 45, 788-856. [CrossRef]

62. Cai, F.; Luis, M.A.F.; Lin, X.; Wang, M.; Cai, L.; Cen, C.; Biskup, E. Anthracycline-induced cardiotoxicity in the chemotherapy treatment of breast cancer: Preventive strategies and treatment (Review). Mol. Clin. Oncol. 2019, 11, 15-23. [CrossRef] [PubMed]

63. Nicolao, P.; Giometto, B. Neurological Toxicity of Ifosfamide. Oncology 2003, 65, 11-16. [CrossRef] [PubMed]

64. Ajithkumar, T.; Parkinson, C.; Shamshad, F.; Murray, P. Ifosfamide Encephalopathy. Clin. Oncol. 2007, 19, 108-114. [CrossRef] [PubMed]

65. Haldar, S.; Dru, C.; Bhowmick, N.A. Mechanisms of hemorrhagic cystitis. Am. J. Clin. Exp. Urol. 2014, 2, 199-208. [PubMed]

66. Edmonson, J.H.; Ryan, L.M.; Blum, R.H.; Brooks, J.S.; Shiraki, M.; Frytak, S.; Parkinson, D.R. Randomized comparison of doxorubicin alone versus ifosfamide plus doxorubicin or mitomycin, doxorubicin, and cisplatin against advanced soft tissue sarcomas. J. Clin. Oncol. 1993, 11, 1269-1275. [CrossRef]

67. Saponara, M.; Stacchiotti, S.; Casali, P.G.; Gronchi, A. (Neo)adjuvant treatment in localised soft tissue sarcoma: The unsolved affair. Eur. J. Cancer 2017, 70, 1-11. [CrossRef]

68. Kozak, K.; Koseła-Paterczyk, H.; Switaj, T.; Klimczak, A.; Ługowska, I.; Falkowski, S.; Tadeusz, M.; Szacht, M.; Rutkowski, P. 104. The long-term outcomes of combined therapy of adult patients with localized synovial sarcoma. Eur. J. Surg. Oncol. 2016, 42, S109. [CrossRef]

69. Fernando, I.N.; Bowden, S.J.; Herring, K.; Brookes, C.L.; Ahmed, I.; Marshall, A.; Grieve, R.; Churn, M.; Spooner, D.; Latief, T.N.; et al. Synchronous versus sequential chemo-radiotherapy in patients with early stage breast cancer (SECRAB): A randomised, phase III, trial. Radiother. Oncol. 2020, 142, 52-61. [CrossRef]

70. Ismaili, N.; Elmajjaoui, S.; Lalya, I.; Boulaamane, L.; Belbaraka, R.; Abahssain, H.; Aassab, R.; Benjaafar, N.; El Guddari, B.E.K.; El Mesbahi, O.; et al. Anthracycline and concurrent radiotherapy as adjuvant treatment of operable breast cancer: A retrospective cohort study in a single institution. BMC Res. Notes 2010, 3, 247. [CrossRef]

71. Greto, D.; Loi, M.; Terziani, F.; Visani, L.; Garlatti, P.; Lo Russo, M.; Teriaca, A.; Muntoni, C.; Delli Paoli, C.; Topulli, J.; et al. A matched cohort study of radio-chemotherapy versus radiotherapy alone in soft tissue sarcoma patients. Radiol. Med. 2019, 124, 301-308. [CrossRef]

72. Nesseler, J.P.; Salleron, J.; Rios, M.; Nickers, P.; Marchal, F.; Brocard, F.; Peiffert, D.; Vogin, G. A retrospective cohort study to assess adjuvant concurrent chemoradiation (CCRT) compared to adjuvant radiation therapy (RT) in the treatment of grade 2 and 3 extremity soft tissue sarcomas. Radiother. Oncol. 2017, 125, 160-167. [CrossRef] [PubMed]

73. Temple, W.J.; Temple, C.L.; Arthur, K.; Schachar, N.S.; Paterson, A.H.; Crabtree, T.S. Prospective cohort study of neoadjuvant treatment in conservative surgery of soft tissue sarcomas. Ann. Surg. Oncol. 1997, 4, 586-590. [CrossRef] [PubMed]

74. Edmonson, J.H.; Petersen, I.A.; Shives, T.C.; Mahoney, M.R.; Rock, M.G.; Haddock, M.G.; Sim, F.H.; Maples, W.J.; O'Connor, M.I.; Gunderson, L.L.; et al. Chemotherapy, irradiation, and surgery for function-preserving therapy of primary extremity soft tissue sarcomas: Initial treatment with ifosfamide, mitomycin, doxorubicin, and cisplatin plus granulocyte macrophage-colony-stimulating factor. Cancer 2002, 94, 786-792. [CrossRef] [PubMed] 
75. DeLaney, T.F.; Spiro, I.J.; Suit, H.D.; Gebhardt, M.C.; Hornicek, F.J.; Mankin, H.J.; Rosenberg, A.L.; Rosenthal, D.I.; Miryousefi, F.; Ancukiewicz, M.; et al. Neoadjuvant chemotherapy and radiotherapy for large extremity soft-tissue sarcomas. Int. J. Radiat. Oncol. Biol. Phys. 2003, 56, 1117-1127. [CrossRef]

76. Kraybill, W.G.; Harris, J.; Spiro, I.J.; Ettinger, D.S.; DeLaney, T.F.; Blum, R.H.; Lucas, D.R.; Harmon, D.C.; Letson, G.D.; Eisenberg, B.; et al. Phase II study of neoadjuvant chemotherapy and radiation therapy in the management of high-risk, high-grade, soft tissue sarcomas of the extremities and body wall: Radiation Therapy Oncology Group Trial 9514. J. Clin. Oncol. 2006, 24, 619-625. [CrossRef]

77. Ryan, C.W.; Montag, A.G.; Hosenpud, J.R.; Samuels, B.; Hayden, J.B.; Hung, A.Y.; Mansoor, A.; Peabody, T.D.; Mundt, A.J.; Undevia, S. Histologic response of dose-intense chemotherapy with preoperative hypofractionated radiotherapy for patients with high-risk soft tissue sarcomas. Cancer 2008, 112, 2432-2439. [CrossRef]

78. MacDermed, D.M.; Miller, L.L.; Peabody, T.D.; Simon, M.A.; Luu, H.H.; Haydon, R.C.; Montag, A.G.; Undevia, S.D.; Connell, P.P. Primary tumor necrosis predicts distant control in locally advanced soft-tissue sarcomas after preoperative concurrent chemoradiotherapy. Int. J. Radiat. Oncol. Biol. Phys. 2010, 76, 1147-1153. [CrossRef]

79. Look Hong, N.J.; Hornicek, F.J.; Harmon, D.C.; Choy, E.; Lin Chen, Y.; Yoon, S.S.; Nielsen, G.P.; Szymonifka, J.; Yeap, B.Y.; DeLaney, T.F.; et al. Neoadjuvant Chemoradiotherapy for Patients with High-Risk Extremity and Truncal Sarcomas: A 10-year Single Institution Retrospective Study. Eur. J. Cancer 2013, 49, 875-883. [CrossRef]

80. Burris, H.A.; Hurtig, J. Radiation Recall with Anticancer Agents. Oncologist 2010, 15, 1227-1237. [CrossRef]

81. Garcia-Barros, M.; Paris, F.; Cordon-Cardo, C.; Lyden, D.; Rafii, S.; Haimovitz-Friedman, A.; Fuks, Z.; Kolesnick, R. Tumor response to radiotherapy regulated by endothelial cell apoptosis. Science 2003, 300, 1155-1159. [CrossRef]

82. Raben, D.; Bianco, C.; Helfrich, B.; Weng, E.; Ciardiello, F.; Harari, P. Interference with EGFR signaling: Paradigm for improving radiation response in cancer treatment. Expert Rev. Anticancer Ther. 2002, 2, 461-471. [CrossRef] [PubMed]

83. Raben, D.; Helfrich, B. Angiogenesis inhibitors: A rational strategy for radiosensitization in the treatment of non-small-cell lung cancer? Clin. Lung Cancer 2004, 6, 48-57. [CrossRef] [PubMed]

84. Yoon, S.S.; Duda, D.G.; Karl, D.L.; Kim, T.-M.; Kambadakone, A.R.; Chen, Y.-L.; Rothrock, C.; Rosenberg, A.E.; Nielsen, G.P.; Kirsch, D.G.; et al. Phase II study of neoadjuvant bevacizumab and radiotherapy for resectable soft tissue sarcomas. Int. J. Radiat. Oncol. Biol. Phys. 2011, 81, 1081-1090. [CrossRef] [PubMed]

85. Pazopanib Hydrochloride Followed by Chemotherapy and Surgery in Treating Patients With Soft Tissue Sarcoma-Full Text View-ClinicalTrials.gov. Available online: https://clinicaltrials.gov/ct2/show/ NCT01446809 (accessed on 21 June 2020).

86. Haas, R.L.M.; Gelderblom, H.; Sleijfer, S.; Van Boven, H.H.; Scholten, A.; Dewit, L.; Borst, G.; Van der Hage, J.; Kerst, J.M.; Nout, R.A.; et al. A phase I study on the combination of neoadjuvant radiotherapy plus pazopanib in patients with locally advanced soft tissue sarcoma of the extremities. Acta Oncol. 2015, 54, 1195-1201. [CrossRef] [PubMed]

87. Ronellenfitsch, U.; Karampinis, I.; Dimitrakopoulou-Strauss, A.; Sachpekidis, C.; Jakob, J.; Kasper, B.; Nowak, K.; Pilz, L.; Attenberger, U.; Gaiser, T.; et al. Preoperative Pazopanib in High-Risk Soft Tissue Sarcoma: Phase II Window-of Opportunity Study of the German Interdisciplinary Sarcoma Group (NOPASS/GISG-04). Ann. Surg. Oncol. 2019, 26, 1332-1339. [CrossRef] [PubMed]

88. Clinical Study of Concurrent Pazopanib and Radiotherapy for Non-metastatic Sarcoma Patients-Full Text View-ClinicalTrials.gov. Available online: https:/clinicaltrials.gov/ct2/show/NCT02575066 (accessed on 21 June 2020).

89. Canter, R.J.; Borys, D.; Olusanya, A.; Li, C.-S.; Lee, L.-Y.; Boutin, R.D.; Christensen, S.D.; Tamurian, R.M.; Monjazeb, A.M. Phase I trial of neoadjuvant conformal radiotherapy plus sorafenib for patients with locally advanced soft tissue sarcoma of the extremity. Ann. Surg. Oncol. 2014, 21, 1616-1623. [CrossRef]

90. Meyer, J.M.; Perlewitz, K.S.; Hayden, J.B.; Doung, Y.-C.; Hung, A.Y.; Vetto, J.T.; Pommier, R.F.; Mansoor, A.; Beckett, B.R.; Tudorica, A.; et al. Phase I trial of preoperative chemoradiation plus sorafenib for high-risk extremity soft tissue sarcomas with dynamic contrast-enhanced MRI correlates. Clin. Cancer Res. 2013, 19, 6902-6911. [CrossRef] 
91. Jakob, J.; Simeonova, A.; Kasper, B.; Ronellenfitsch, U.; Rauch, G.; Wenz, F.; Hohenberger, P. Combined sunitinib and radiation therapy for preoperative treatment of soft tissue sarcoma: Results of a phase I trial of the German interdisciplinary sarcoma group (GISG-03). Radiat. Oncol. 2016, 11, 77. [CrossRef]

92. Lewin, J.; Khamly, K.K.; Young, R.J.; Mitchell, C.; Hicks, R.J.; Toner, G.C.; Ngan, S.Y.K.; Chander, S.; Powell, G.J.; Herschtal, A.; et al. A phase Ib/II translational study of sunitinib with neoadjuvant radiotherapy in soft-tissue sarcoma. Br. J. Cancer 2014, 111, 2254-2261. [CrossRef]

93. Raviraj, J.; Bokkasam, V.K.; Kumar, V.S.; Reddy, U.S.; Suman, V. Radiosensitizers, radioprotectors, and radiation mitigators. Indian J. Dent. Res. 2014, 25, 83-90. [CrossRef]

94. Elming, P.B.; Sørensen, B.S.; Oei, A.L.; Franken, N.A.P.; Crezee, J.; Overgaard, J.; Horsman, M.R. Hyperthermia: The Optimal Treatment to Overcome Radiation Resistant Hypoxia. Cancers 2019, 11, 60. [CrossRef] [PubMed]

95. Bull, J.M.C. An Update on the Anticancer Effects of a Combination of Chemotherapy and Hyperthermia. Cancer Res. 1984, 44, 4853s-4856s. [PubMed]

96. Pennacchioli, E.; Fiore, M.; Gronchi, A. Hyperthermia as an adjunctive treatment for soft-tissue sarcoma. Expert Rev. Anticancer 2009, 9, 199-210. [CrossRef] [PubMed]

97. Dewey, W.C.; Hopwood, L.E.; Sapareto, S.A.; Gerweck, L.E. Cellular responses to combinations of hyperthermia and radiation. Radiology 1977, 123, 463-474. [CrossRef]

98. Yagawa, Y.; Tanigawa, K.; Kobayashi, Y.; Yamamoto, M. Cancer immunity and therapy using hyperthermia with immunotherapy, radiotherapy, chemotherapy, and surgery. J. Cancer Metastasis Treat 2017, 3, 218. [CrossRef]

99. Jha, S.; Sharma, P.K.; Malviya, R. Hyperthermia: Role and Risk Factor for Cancer Treatment. Achiev. Life Sci. 2016, 10, 161-167. [CrossRef]

100. Hypofractionated Radiotherapy with Hyperthermia in Unresectable or Marginally Resectable Soft Tissue Sarcomas. Available online: https://clinicaltrials.gov/ct2/show/NCT03989596 (accessed on 21 June 2020).

101. Arslan, S.A.; Ozdemir, N.; Sendur, M.A.; Eren, T.; Ozturk, H.F.; Aral, I.P.; Soykut, E.D.; Inan, G.A. Hyperthermia and radiotherapy combination for locoregional recurrences of breast cancer: A review. Breast Cancer Manag. 2017, 6, 117-126. [CrossRef]

102. Bakker, A.; Van der Zee, J.; Van Tienhoven, G.; Kok, H.P.; Rasch, C.R.N.; Crezee, H. Temperature and thermal dose during radiotherapy and hyperthermia for recurrent breast cancer are related to clinical outcome and thermal toxicity: A systematic review. Int. J. Hyperth. 2019, 36, 1023-1038. [CrossRef]

103. Notter, M.; Piazena, H.; Vaupel, P. Hypofractionated re-irradiation of large-sized recurrent breast cancer with thermography-controlled, contact-free water-filtered infra-red-A hyperthermia: A retrospective study of 73 patients. Int. J. Hyperth. 2017, 33, 227-236. [CrossRef]

104. Hyperthermia and Radiotherapy in the Treatment for In-field Recurrent and Radiation-induced Soft Tissue and Bone Sarcomas. Available online: https:/clinicaltrials.gov/ct2/show/NCT04398095 (accessed on 21 June 2020).

105. Sapareto, S.A. Thermal isoeffect dose: Addressing the problem of thermotolerance. Int. J. Hyperth. 1987, 3, 297-305. [CrossRef]

106. Leopold, K.A.; Harrelson, J.; Prosnitz, L.; Samulski, T.V.; Dewhirst, M.W.; Oleson, J.R. Preoperative hyperthermia and radiation for soft tissue sarcomas: Advantage of two vs one hyperthermia treatments per week. Int. J. Radiat. Oncol. Biol. Phys. 1989, 16, 107-115. [CrossRef]

107. Indelicato, D.J.; Meadows, K.; Gibbs, C.P.; Morris, C.G.; Scarborough, M.T.; Zlotecki, R.A. Effectiveness and Morbidity Associated With Reirradiation in Conservative Salvage Management of Recurrent Soft-Tissue Sarcoma. Int. J. Radiat. Oncol. Biol. Phys. 2009, 73, 267-272. [CrossRef] [PubMed]

108. Feldmann, H.J.; Seegenschmiedt, M.H.; Molls, M. Hyperthermia-Its actual role in radiation oncology. Part III: Clinical rationale and results in deep seated tumors. Strahlenther. Onkol. 1995, 171, 251-264. [PubMed]

109. Miller, M.W.; Nyborg, W.L.; Dewey, W.C.; Edwards, M.J.; Abramowicz, J.S.; Brayman, A.A. Hyperthermic teratogenicity, thermal dose and diagnostic ultrasound during pregnancy: Implications of new standards on tissue heating. Int. J. Hyperth. 2002, 18, 361-384. [CrossRef] [PubMed]

110. Celsius42 GmbH. FAQ. Available online: https://www.celsius42.de/en/faq (accessed on 21 June 2020).

111. Haas, R.L.; Van Beek, S.; Betgen, A.; Ali, S.; Schneider, C.J.; Diddens, F.H.; Scholten, A.N.; Koetsveld, F.; Remeijer, P. Substantial Volume Changes and Plan Adaptations During Preoperative Radiation Therapy in Extremity Soft Tissue Sarcoma Patients. Pract. Radiat. Oncol. 2019, 9, 115-122. [CrossRef] 
112. Delisca, G.O.; Alamanda, V.K.; Archer, K.R.; Song, Y.; Schwartz, H.S.; Holt, G.E. Tumor size increase following preoperative radiation of soft tissue sarcomas does not affect prognosis. J. Surg. Oncol. 2013, 107, 723-727. [CrossRef]

113. Messiou, C.; Bonvalot, S.; Gronchi, A.; Vanel, D.; Meyer, M.; Robinson, P.; Morosi, C.; Bloem, J.L.; Terrier, P.H.; Lazar, A.; et al. Evaluation of response after pre-operative radiotherapy in soft tissue sarcomas; the European Organisation for Research and Treatment of Cancer-Soft Tissue and Bone Sarcoma Group (EORTC-STBSG) and Imaging Group recommendations for radiological examination and reporting with an emphasis on magnetic resonance imaging. Eur. J. Cancer 2016, 56, 37-44. [CrossRef]

114. Vaynrub, M.; Taheri, N.; Ahlmann, E.R.; Yao, C.; Fedenko, A.N.; Allison, D.C.; Chawla, S.P.; Menendez, L.R. Prognostic value of necrosis after neoadjuvant therapy for soft tissue sarcoma. J. Surg. Oncol. 2015, 111, 152-157. [CrossRef]

115. Mullen, J.T.; Hornicek, F.J.; Harmon, D.C.; Raskin, K.A.; Chen, Y.-L.; Szymonifka, J.; Yeap, B.Y.; Choy, E.; DeLaney, T.F.; Nielsen, G.P. Prognostic Significance of Treatment-Induced Pathologic Necrosis in Extremity and Truncal Soft Tissue Sarcoma after Neoadjuvant Chemoradiotherapy. Cancer 2014, 120, 3676-3682. [CrossRef]

116. Salah, S.; Lewin, J.; Amir, E.; Abdul Razak, A. Tumor necrosis and clinical outcomes following neoadjuvant therapy in soft tissue sarcoma: A systematic review and meta-analysis. Cancer Treat. Rev. 2018, 69, 1-10. [CrossRef]

117. Wardelmann, E.; Haas, R.L.; Bovée, J.V.M.G.; Terrier, P.; Lazar, A.; Messiou, C.; LePechoux, C.; Hartmann, W.; Collin, F.; Fisher, C.; et al. Evaluation of response after neoadjuvant treatment in soft tissue sarcomas; the European Organization for Research and Treatment of Cancer-Soft Tissue and Bone Sarcoma Group (EORTC-STBSG) recommendations for pathological examination and reporting. Eur. J. Cancer 2016, 53, 84-95. [CrossRef]

118. Mortaji, P.; Lebduska, E. The Dangers of Using Tumor Markers to Evaluate Nonspecific Symptoms: A Teachable Moment. JAMA Intern. Med. 2020, 180, 1004. [CrossRef] [PubMed]

119. Kondo, T.; Kawai, A. A proteomics approach for the development of sarcoma biomarkers. EuPA Open Proteom. 2014, 4, 121-128. [CrossRef]

120. Burns, J.; Wilding, C.P.; Jones, R.L.; Huang, P.H. Proteomic research in sarcomas-current status and future opportunities. Semin. Cancer Biol. 2020, 61, 56-70. [CrossRef] [PubMed]

121. Kane, J.M.; Magliocco, A.; Zhang, Q.; Wang, D.; Klimowicz, A.; Harris, J.; Simko, J.; DeLaney, T.; Kraybill, W.; Kirsch, D.G. Correlation of High-Risk Soft Tissue Sarcoma Biomarker Expression Patterns with Outcome following Neoadjuvant Chemoradiation. Available online: https://www.hindawi.com/journals/sarcoma/ 2018/8310950/ (accessed on 21 June 2020).

122. Prospective Biomarkers for Chemotherapy Selection in Sarcoma. Available online: http://sarcomahelp.org/ articles/chemotherapy-biomarkers.html (accessed on 21 June 2020).

123. Caruso, C.; Garofalo, C. Pharmacogenomics Biomarkers of Soft Tissue Sarcoma Therapies. Front. Oncol. 2020, 10, 509. [CrossRef] [PubMed]

124. Pasquali, S.; Braglia, L.; Chibon, F.; Coindre, J.M.; Italiano, A.; Romagosa, C.; Bague, S.; Dei Tos, A.P.; Palmerini, E.; Quagliuolo, V.; et al. The prognostic value of CINSARC in a randomised trial comparing histotype-tailored neoadjuvant chemotherapy versus standard chemotherapy in patients with high-risk soft-tissue sarcomas (ISG-STS 1001). J. Clin. Oncol. 2020, 38, e23531. [CrossRef]

125. Han, A.; Chen, E.H.; Niedt, G.; Sherman, W.; Ratner, D. Neoadjuvant Imatinib Therapy for Dermatofibrosarcoma Protuberans. Arch. Derm. 2009, 145, 792-796. [CrossRef]

126. Rutkowski, P.; Gronchi, A.; Hohenberger, P.; Bonvalot, S.; Schöffski, P.; Bauer, S.; Fumagalli, E.; Nyckowski, P.; Nguyen, B.-P.; Kerst, J.M.; et al. Neoadjuvant Imatinib in Locally Advanced Gastrointestinal Stromal Tumors (GIST): The EORTC STBSG Experience. Ann. Surg. Oncol. 2013, 20, 2937-2943. [CrossRef]

127. Demicco, E.G.; Maki, R.G.; Lev, D.C.; Lazar, A.J. New Therapeutic Targets in Soft Tissue Sarcoma. Adv. Anat. Pathol. 2012, 19, 170-180. [CrossRef]

128. Italiano, A. Targeting epigenetics in sarcomas through EZH2 inhibition. J. Hematol. Oncol. 2020, $13,3$. [CrossRef]

129. Doebele, R.C.; Drilon, A.; Paz-Ares, L.; Siena, S.; Shaw, A.T.; Farago, A.F.; Blakely, C.M.; Seto, T.; Cho, B.C.; Tosi, D.; et al. Entrectinib in patients with advanced or metastatic NTRK fusion-positive solid tumours: Integrated analysis of three phase 1-2 trials. Lancet Oncol. 2020, 21, 271-282. [CrossRef] 
130. Xie, X.; Ghadimi, M.P.; Young, E.D.; Belousov, R.; Zhu, Q.; Liu, J.; Lopez, G.; Colombo, C.; Peng, T.; Reynoso, D.; et al. Combining EGFR and mTOR blockade for the treatment of epithelioid sarcoma. Clin. Cancer Res. 2011, 17, 5901-5912. [CrossRef]

131. Judson, I.; Morden, J.P.; Kilburn, L.; Leahy, M.; Benson, C.; Bhadri, V.; Campbell-Hewson, Q.; Cubedo, R.; Dangoor, A.; Fox, L.; et al. Cediranib in patients with alveolar soft-part sarcoma (CASPS): A double-blind, placebo-controlled, randomised, phase 2 trial. Lancet Oncol. 2019, 20, 1023-1034. [CrossRef]

132. Ayodele, O.; Razak, A.R.A. Immunotherapy in soft-tissue sarcoma. Curr. Oncol. 2020, 27, 17-23. [CrossRef] [PubMed]

133. Wilky, B.A.; Trucco, M.M.; Subhawong, T.K.; Florou, V.; Park, W.; Kwon, D.; Wieder, E.D.; Kolonias, D.; Rosenberg, A.E.; Kerr, D.A.; et al. Axitinib plus pembrolizumab in patients with advanced sarcomas including alveolar soft-part sarcoma: A single-centre, single-arm, phase 2 trial. Lancet Oncol. 2019, 20, 837-848. [CrossRef]

134. Lewin, J.; Davidson, S.; Anderson, N.D.; Lau, B.Y.; Kelly, J.; Tabori, U.; Salah, S.; Butler, M.O.; Aung, K.L.; Shlien, A.; et al. Response to Immune Checkpoint Inhibition in Two Patients with Alveolar Soft-Part Sarcoma. Cancer Immunol. Res. 2018, 6, 1001-1007. [CrossRef] [PubMed]

135. Butrynski, J.E.; D’Adamo, D.R.; Hornick, J.L.; Cin, P.D.; Antonescu, C.R.; Jhanwar, S.C.; Ladanyi, M.; Capelletti, M.; Rodig, S.J.; Ramaiya, N.; et al. Crizotinib in ALK-Rearranged Inflammatory Myofibroblastic Tumor. N. Engl. J. Med. 2010, 363, 1727-1733. [CrossRef]

(C) 2020 by the authors. Licensee MDPI, Basel, Switzerland. This article is an open access article distributed under the terms and conditions of the Creative Commons Attribution (CC BY) license (http://creativecommons.org/licenses/by/4.0/). 